Portland State University

PDXScholar

Business Faculty Publications and

Presentations

The School of Business

9-18-2018

\title{
Do Pro-Diversity Policies Improve Corporate Innovation?
}

Roger C. Mayer

North Carolina State University at Raleigh

Richard S. Warr

North Carolina State University at Raleigh

Jing Zhao

Portland State University, jizhao@pdx.edu

Follow this and additional works at: https://pdxscholar.library.pdx.edu/busadmin_fac

Part of the Business Administration, Management, and Operations Commons, and the Business and Corporate Communications Commons

Let us know how access to this document benefits you.

\section{Citation Details}

Mayer, Roger C.; Warr, Richard S.; and Zhao, Jing, "Do Pro-Diversity Policies Improve Corporate Innovation?" (2018). Business Faculty Publications and Presentations. 122.

https://pdxscholar.library.pdx.edu/busadmin_fac/122

This Post-Print is brought to you for free and open access. It has been accepted for inclusion in Business Faculty Publications and Presentations by an authorized administrator of PDXScholar. Please contact us if we can make this document more accessible: pdxscholar@pdx.edu. 


\section{Do Pro-Diversity Policies Improve Corporate Innovation? ${ }^{\dagger}$}

${ }^{\dagger}$ We wish to thank Raghu Rau (editor) and an anonymous referee, whose comments and suggestions have substantially improved this paper. We also thank Antje Berndt, Seong Byun (discussant), Jesse Ellis, Srini Krishnamurthy, Mark Walker, and participants at Eastern Finance Association Annual Meeting, Financial Management Association Annual Meeting, Southern Finance Association Annual Meeting, and North Carolina State University Brown Bag for helpful comments. Jing Zhao gratefully acknowledges financial support from the Cameron Research Fellowship in Finance at the School of Business, Portland State University. 


\title{
Roger C. Mayer, Richard S. Warr, and \\ Jing Zhao*
}

\begin{abstract}
Using new product announcements, patents, and patent citations as measures of corporate innovation, we find that corporate policies that promote more pro-diversity cultures, specifically treatment of women and minorities, enhance future innovative efficiency. This positive effect is stronger during economic downturns and in firms that are more innovative, value intangibles and human capital more highly, have greater growth options, have higher cash flow, and have stronger governance. Pro-diversity policies also increase firm value via this stimulating effect on innovative efficiency. Our results suggest a channel through which workforce diversity may enhance firm value.
\end{abstract}

${ }^{*}$ Roger C. Mayer is a Professor of Management, Innovation \& Entrepreneurship in the Poole College of Management at North Carolina State University in Raleigh, NC. Richard S. Warr is a Professor of Finance in the Poole College of Management at North Carolina State University in Raleigh, NC. Jing Zhao is an Assistant Professor of Finance in the School of Business at Portland State University in Portland, OR. 
Even though the mantra that firms "value diversity" is frequently heard both in business and academia, surprisingly little work exists in the academic literature that examines how diversity (defined as race, sex, and sexual orientation) impacts financial outcomes and firm value. In this paper, we explore whether firms that promote diversity within their organizations are rewarded with tangible outcomes in the form of new innovations and new product announcements, along with patents and citations on patents.

We hypothesize that firms that develop a diverse workforce and a culture of inclusion will have greater innovative efficiency, ultimately leading to greater innovation output. Prodiversity practices enhance innovative efficiency because a more diverse hiring policy increases the potential pool from which a firm is able to recruit talented and creative employees. In addition, a wider range of views, backgrounds, and expertise can help innovative problem solving, and a culture of inclusion may help attract and retain talent. We propose that through the channel of corporate innovation, pro-diversity policies can impact firm value. Our null hypothesis is that pro-diversity policies are merely designed to make the company look better to the outside world, or worse, that such policies are a managerial indulgence and predicts that investment in such policies will result in the destruction of shareholder value (Jensen, 1986).

Our exploration is motivated in part by Hirshleifer, Hsu, and Li (2013), who document a link between the ability of the firm to develop and create new technologies and the subsequent financial performance of the firm. They measure technological innovation as patents and citations generated per research and development $(R \& D)$ dollar. This measure of "innovative efficiency" is positively related to future stock returns. Our paper is also motivated by work in the management literature that shows that diverse teams and organizations tend to be more 
innovative (see, e.g., Talke, Salomo, and Rost, 2010; Østergaard, Timmermans, and Kristinsson, 2011).

Our primary measure of innovation is new product announcements from the Capital IQ's Key Developments database, which capture innovation that does not necessarily lead to patents. Prior research links new product development to positive firm financial outcomes (see, e.g., Chaney, Devinney, and Winer, 1991, for an early study). As a robustness check, we also use the National Bureau of Economic Research (NBER) patent and citation database to create measures of innovative efficiency. ${ }^{1}$ We scale the patent and citation measures by the time series of R\&D expense and repeat our main tests. All of our tests are subject to extensive controls.

We use the MSCI ESG STATS database to create measures of a firm's pro-diversity policies. The MSCI ESG STATS data record whether firms have a range of policies and characteristics that are either "strengths" in diversity or "concerns." Such measures include whether the Chief Executive Officer (CEO) is a woman, whether women or minorities are promoted to key positions, whether minority groups and women are represented on the board, the presence of benefits aimed at work-life balance, hiring programs aimed at disabled workers, and whether the firm has progressive policies toward lesbian, gay, bisexual, and transgender (LGBT) employees.

We find that pro-diversity policies are positively related to the number of new product announcements per R\&D dollar spent by a firm. Our results are robust to addressing endogeneity using Granger (1969) causality tests. More specifically, we find that lagged changes in diversity policies positively and significantly predict future changes in innovative efficiency but not the

\footnotetext{
${ }^{1}$ Prior literature has documented a positive relation between patent innovation and firm value (Pakes 1985; Hall, Jaffe, and Trajtenberg, 2005).
} 
other way around. ${ }^{2}$ Further tests show that the positive effect of pro-diversity policies on innovative efficiency is stronger during recessions, including the 2008 financial crisis, suggesting that building a reputation of pro-diversity and a culture of inclusion pays off especially when investors and the economy at large suffer extraordinary uncertainty and risk and a severe crisis of trust and confidence, and when the reward for being trustworthy substantially increases. $^{3}$

We address potential concerns that our results are a "Silicon Valley" effect by explicitly excluding California-based firms and still finding that our main results are qualitatively unaffected. The positive effect of pro-diversity policies is also more pronounced in more innovative firms; firms where intangibles including human capital and employees are more valuable; firms with greater growth options; firms in industries with fewer women in the labor force and thus have more to gain from attracting and retaining (talented) women and other minorities; firms with lower leverage, higher cash flow, and less financial constraints; and firms with stronger governance.

We find that pro-diversity policies enhance firm value (as measured by Tobin's Q) via their positive effect on innovative efficiency, in particular for a sample of firms that actively and frequently engage in new product innovation. Therefore, we suggest that the effect of diversity on innovation represents a channel through which such policies can create firm value. Our results are robust to alternative measures of innovative efficiency and to firm-, industry-, and year-fixed effects, and to various model specifications. In addition, when we replace the dependent variable, new product announcements, with innovative efficiency measures based on patents and citations, our major findings remain qualitatively unchanged. Our results provide an explanation for why

\footnotetext{
${ }^{2}$ We thank the referee for suggesting this important test to control for endogeneity.

${ }^{3}$ We thank the editor for suggesting this test.
} 
promoting diverse workforces can result in greater productivity and innovative efficiency from those employees, which in turn leads to greater shareholder value.

Our study makes three major contributions. First, we document a positive effect of diversity-related policies on corporate innovation. Second, we show that more favorable diversity-related policies enhance the positive effect that innovation has on firm value. ${ }^{4}$ Finally, we demonstrate the positive value of corporate diversity policies during a financial crisis period.

The remainder of our paper is organized as follows. In the next section, we review the literature on workforce diversity and corporate innovative efficiency and develop testable hypotheses. In Section II, we describe the data, variable construction, and research methods. Section III examines the effects of pro-diversity policies on a firm's innovative efficiency using the new product announcements, while Section IV summarizes our robustness tests using patent and citation data. We conclude in Section V.

\section{Literature Review and Hypothesis Development}

\section{A. Diversity Policies}

Evidence exists that diversity and pro-diversity policies may improve corporate performance. First, a more pro-diversity hiring policy increases the depth of the potential employee pool from which the firm can hire talent. Second, a wider range of views, backgrounds, and experiences may contribute directly to more innovative problem solving (Horwitz and Horwitz, 2007). Finally, by being more pro-diversity, a firm may attract and retain

\footnotetext{
${ }^{4}$ Previous research has examined the relation between innovation or innovative efficiency and various factors, including aggregate stock returns (Hsu, 2009), market liquidity (Fang, Tian, and Tice, 2014), state anti-takeover laws (Atanassov, 2013), corporate governance (Chemmanur and Tian, 2014), corporate philanthropy (Bereskin, Campbell, and Hsu, 2014), analyst coverage (He and Tian, 2013), institutional ownership (Aghion, Van Reenen, and Zingales, 2013), hedge fund ownership and activism (Brav et al., 2015; Wang and Zhao, 2015 ), bank loan contracting (Francis et al., 2012), bank competition (Cornaggia et al., 2015), CEO overconfidence (Hirshleifer, Low, and Teoh, 2012), and board interlocks (Helmers, Patnam, and Rau, 2015), among others. See Chemmanur and Fulghieri (2014) for a comprehensive survey of this literature.
} 
talent even if this talent is not among the groups that are typically the focus of diversity policies. Being seen to be pro-diversity may create a halo effect for the firm and its brands.

Addressing the role of diversity in organizations, Richard (2000) finds that in a study of the banking industry, racial diversity appeared to add value as measured by productivity, return on equity, and market value. Blazovich et al. (2013) consider LGBT measures and corporate performance and find that LGBT-friendly policies lead to higher firm value and productivity, and furthermore, these relations are stronger for firms that demand more highly skilled labor. ${ }^{5}$ In a recent working paper, Gao and Zhang (2015) find a significant increase in patent production for firms located in states that enact anti-discrimination laws. In a meta-analysis, Horwitz and Horwitz (2007) report that more diverse workforces are likely to result in more creative solutions to problems. This finding is supported by Talke et al. (2010) who find evidence that top management diversity increases firm performance by increasing the innovativeness of the new product portfolio. Østergaard et al. (2011) show, using survey data, a relation between employee diversity and innovation, while Bantel and Jackson (1989) show that more diverse top management teams lead to greater innovation in banks.

At the team level, Van der Vegt and Janssen (2003) show that more heterogeneous teams lead to greater levels of innovation. Hewlett, Marshall, and Sherbin (2013), using a combination of surveys and case studies, report a correlation between diversity and market share growth. Faems, Van Looy, and Debackere (2005) find that firms with diverse networks of interorganizational collaboration are better able to commercialize and improve products.

\section{B. New Product Announcements}

\footnotetext{
${ }^{5}$ The Blazovich et al. (2013) paper contains a very thorough review of other literature that examines the relation between LGBT policies and firm performance. Many of these previous studies rely on employee-level survey data.
} 
The creation of new products has been found to be linked to firm value. In an early study, Chaney et al. (1991) find that a new product announcement is greeted with a 25 basis point abnormal announcement return. New product introductions have been found to have a positive impact on firm value (as measured by book to market) (Pauwels et al., 2004) and to increase profitability (Bayus, Erickson, and Jacobson, 2003). New product announcements are greeted by investors with a positive stock price reaction (Srinivasan et al., 2009) and lead to sustained stock market performance (measured using a four-factor model) (Sood and Tellis, 2009).

In our study, we use a relatively new data set, the Capital IQ Key Developments database, that reports numerous types of corporate events, one of which is new product announcements. A recent paper by Cohn, Gurun, and Moussawi (2016) uses the product announcements from Capital IQ to test whether managerial short termism impacts market responses to product announcements.

\section{Patents and Citations}

Griliches, Pakes, and Hall (1988) document how patent activity is a measure of innovative activity, which can be used to measure "inventive output" and which provides a framework for relating firms' R\&D activity to patent creation. Other authors have documented the relation between innovation and firm performance (Blundell, Griffith, and van Reenen, 1999; Hall, 1999). Hirshleifer et al. (2013) demonstrate a positive relation between innovative efficiency, stock returns, and investor attention. Several other studies also find a positive relation between patent activity and returns (Deng, Lev, and Narin, 1999; Lanjouw and Schankerman, 2004; Gu, 2005; Matolcsy and Wyatt, 2008; Pandit, Wasley, and Zach, 2011). 


\section{Hypothesis Development}

The goal of our paper is to examine how pro-diversity policies impact a firm's innovative efficiency and how these policies result in the value creation. We consider pro-diversity policies as being a broad range of activities that impact the diversity and the makeup of the workforce through the promotion and treatment of minorities, women, the disabled, and LGBT employees. These policies could foster greater innovation by garnering more diverse viewpoints resulting in creative solutions and innovations. Pro-diversity policies also enable the firm to attract and retain higher-quality talent and potentially create a halo effect for the firm with other employees and customers.

We define innovative efficiency as some measure of innovative output (such as new product announcements) that is then scaled by some measure of resource inputs (such as R\&D). We hypothesize that to build greater innovative efficiency, a firm must look to create a culture and environment of diversity and inclusion. This focus on diversity will attract and recognize talent, regardless of whether that talent is from a minority group.

Therefore, our main hypothesis is

$\mathrm{H}_{1}$ : Firms that promote a diverse and inclusive workforce will be rewarded with greater innovative efficiency.

Empirically, we will measure innovative efficiency using new product announcements as our primary tests. As a robustness test, we will also consider both patents and citations as alternative measures of innovative efficiency.

As discussed earlier, our null hypothesis is that pro-diversity measures have no effect on innovative efficiency, although they may serve some other goal of the firm. An alternative 
hypothesis is that pro-diversity policies are an expensive managerial indulgence that serve to harm firm value.

\section{Data and Method}

\section{A. Measuring Pro-Diversity Policies}

To measure pro-diversity policies, we use the MSCI ESG STATS data set (described in detail by Landier, Nair, and Wulf, 2009). The MSCI ESG STATS database ranks U.S. publicly traded firms on eight broad categories, including environment, community, human rights, employee relations, diversity, customers, products, and corporate governance. Firms are rated on strengths and concerns on individual items within each category. Each firm is assigned a score of 0 or 1 for each strength or concern based on whether the firm meets the screen criteria. MSCI also screens firms based on their business involvement in controversial industries, such as alcohol, gambling, firearms, military, nuclear power, and tobacco.

The data can be used to measure employee-related policies, including diversity policies, in a variety of ways. For example, Blazovich et al. (2013) study LGBT policies and use just one variable (the presence of gay and lesbian policies) in the data set. Alternatively, for a broad measure of employee treatment, a simple index can be created by adding up the scores in a particular area or by adding scores across a selection of measures (Fisman, Nair, and Heal, 2005; Landier et al. 2009; Ertugrul, 2013). Bae, Kang, and Wang (2011) create a five-measure index using union relations, cash profit sharing, employee involvement, retirement benefits, and health and safety strength. Turban and Greening (1997) add up the scores in each major category and 
produce five indices. ${ }^{6}$ Finally, Chang, Fu, Low, and Zhang (2015) create a binary measure of whether the firm is above or below the Bae et al. (2011) employee treatment index.

The MCSI ESG measures that pertain to diversity are grouped into two broad categories - namely, Diversity Strengths and Diversity Concerns. Diversity strengths measure female and minority representation in key positions such as the CEO or the board. Also included are work-life benefits, contracting with women and minorities, employment of disabled and gay and lesbian workers. Diversity concerns cover controversies related to women and minorities and lack of women and minorities in leadership positions. In addition to these specific categories, each area has a generic "other" grouping. We calculate the net strengths of diversity as the difference between Diversity strengths and Diversity concerns (DIV = Diversity strengths Diversity concerns). Full definitions of all these variables are provided in the Appendix.

Table I reports the summary statistics for the diversity measures. The highest mean strength score is for item B-Promotion of Minorities and Women—which has a mean of 0.199, indicating that $20 \%$ of firms score a 1 on this metric. Employment of Underrepresented Groups (item $\mathrm{H}$ ) also has an average of about $20 \%$, but this variable is much less frequently reported. Among the concerns, items B and C, nonrepresentation and Board of Directors composition, respectively, are the highest, indicating that $36 \%$ of firms have no women in senior positions, and $42 \%$ have no women on their boards. On average, the net diversity strengths equal 0.038 $(D I V)$. It should be recognized that our net diversity measure, $D I V$, is merely an index and does not measure per se whether a firm is "pro-diversity"; it does, however, facilitate comparisons across firms and with firms.

\footnotetext{
${ }^{6}$ These index approaches are similar to other indices used in corporate finance, such as those of Gompers, Ishii, and Metrick (2003) and Bebchuk, Cohen, and Ferrell (2009).
} 


\section{B. Measuring Innovation}

In measuring innovation, it is important to distinguish between innovative output—-for example, a raw count industry-scaled new product announcements — and innovative efficiencyfor example, an industry scaled count of patents, citations, or new products that is also scaled by historic R\&D expenses. A firm could generate more innovative output simply by being larger or by having more labor or R\&D costs, but innovative efficiency takes into consideration $R \& D$ inputs and thus is a measure of how well or efficiently the firm applies its R\&D resources. In our method, we measure raw innovative output as number of product announcements and innovative efficiency as number of product announcements scaled by R\&D expense. As a robustness check, we use patents and citations of patents in place of new product announcements and construct these variables in line with the methods used by prior researchers.

\section{New Product Announcements}

We identify new product information from Capital IQ's Key Development database on new product announcements over 2001-2014. The Key Development database consists of information regarding new product development collected from more than 20,000 public news sources, company press releases, regulatory filings, call transcripts, investor presentations, stock exchanges, regulatory websites, and company websites. These data are then examined and filtered by Capital IQ's analysts to eliminate duplicate and extraneous information, identify the companies involved, and then categorize the data based on the type and nature of the event. Event categories include new product announcements, new client announcements, executive changes, mergers and acquisitions rumors, changes in corporate guidance, delayed filings, and U.S. Securities and Exchange Commission inquiries. We obtain only the new product announcements as these announcements pertain directly to specific project or product 
development. For each sample of firms in our MSCI database, we compute the annual number of new product announcements for each calendar year over 2001-2014.

Specifically, Prod is the annual number of new product announcements for a firm in calendar year $t+1$. $\operatorname{Ln}(1+$ Prod $)$ is the natural logarithm of one plus Prod and is our innovation output measures. We take natural logarithm to control for any skewness. To measure innovative efficiency, we construct the following efficiency measure: $\operatorname{Ln}[(1+\operatorname{Prod}) /(1+R \& D)]$, where $\mathrm{R} \& \mathrm{D}$ expenses are measured at the fiscal year end prior to calendar year $t+1$. Note that while our focus is on the relation between diversity policies and innovative efficiency, we also report tests using the innovative output, in an attempt to facilitate a more complete comparison and picture.

Table II, Panel A presents the new product announcement measures. The average firm in our sample has 3.5 new product announcements per year. The remaining new product output and efficiency metrics are constructed as discussed above.

\section{Patents and Citations}

We define Patents as the total count of patents applied for (and ultimately granted) by the firm in a calendar year. As noted by Hall, Jaffe, and Trajtenberg (2001) and Griliches et al. (1988), the relevant year is patent application year instead of grant year because the former more accurately captures the time of the actual innovation being made. Typically, there is a time lag of two to three years between the application and the grant date. Following these authors, we create the variable Patents_USPTO defined as Patents scaled by the average number of patents filed across all firms in the same application year and the same U.S. Patent and Trademark Office (USPTO) technological class. Similarly, we create Patents_HJT which equals Patents divided by the average number of patents filed across all firms in the same application year and the same technological category from Hall et al. (2001; henceforth HJT). 
Scaling Patents by the industry and technology category measures serves an additional purpose in that it mitigates truncation bias that occurs toward the end of the sample. For example, a firm might apply for a patent, but because of the two- to three-year delay in getting a patent awarded, the patent application will not show up in the data set. Consequently, the raw number of patents declines toward the end of the data period because the data records only patent applications that are subsequently approved. As the industry or technology category will also suffer from this bias, scaling by one of these metrics should result in an unbiased ratio.

While patents are one measure of the quantity of innovation, a simple count of patents does not distinguish breakthrough innovations from more marginal contributions. Future citations received on the patent, on the other hand, capture the impact of a patent (Trajtenberg, 1990; Hall et al., 2001). Therefore, we estimate the variable Citations as citations received in life on all patents filed for in a calendar year by a firm. This variable measures the technological impact of the firm's patents - that is, to what degree future creativity depends on them.

Patent citations also suffer from truncation bias. Thus, a large value of Citations may not necessarily represent a more important patent but may simply be an artifact of the measurement period chosen. Moreover, different industries may have different patent citation rates. We correct for these biases by constructing two additional variables (using an approach similar to the one we used for the patent data). Citations_USPTO equals Citations divided by the total number of citations received in life on all patents filed in the same USPTO class and the sample application year. Citations_HJT equals Citations divided by the HJT technological category for the same application year.

Following the method of Hirshleifer et al. (2013), we scale the patent and citation measures discussed above by the five-year cumulative $R \& D$ expenditures assuming an annual 
depreciation rate of $20 \%$, because prior literature suggests that $R \& D$ expenses over the preceding five years all contribute to successful patent applications filed in year $t$ (Chan, Lakonishok, and Sougiannis, 2001; Lev, Sarath, and Sougiannis, 2005; Hirshleifer et al., 2013). We assign zero to missing R\&D when computing the denominator (Hirshleifer et al., 2013). For our regression analysis, we take the natural logarithms of one plus one of the patent and citation measures as our dependent variables to mitigate the effects of skewness. Table II, Panel A presents summary statistics for these measures. The average firm has 31 patents and about 68 citations. Because the NBER patent and citation database ends in 2006, our patent and citation measures are available during 1996-2006.

\section{Other Firm Data}

We supplement the new product and MSCI data with firm-level financial statement information from Compustat, stock return data from the Center for Research in Security Prices (CRSP), executive compensation and insider ownership data from Standard \& Poor's ExecuComp, and corporate governance and board of directors' information from Risk Metrics. To mitigate any sample selection bias, we follow prior literature (Atanassov, 2013; Chemmanur and Tian, 2014; He and Tian, 2013) and assign value zero to firm-years with missing patent and citation data, or missing $\mathrm{R} \& \mathrm{D}$, and include these observations in our analysis.

In Table II, Panel B, we present firm characteristics. The sample firms are generally quite large, and this is a result of the intersection of the Risk Metrics and MSCI ESG data. ${ }^{7}$ The mean firm in our sample has a market value of $\$ 8.6$ billion and generates $\$ 6.6$ billion in sales, invests about $2.7 \%$ of assets in R\&D annually, and is quite profitable with an average return of assets

\footnotetext{
${ }^{7}$ The coverage of MSCI was the 500 largest firms from 1991-2000, extended to the 1,000 largest firms from 2001 to 2002, and since 2003 the data set has included the 3,000 largest firms. However, Risk Metrics data are only available for the S\&P 1500, so our data are biased toward larger firms.
} 
(ROA) of $14 \%$. Overall the average firm has a low level of leverage of about $22 \%$ of assets. Consistent with firms being by and large growth firms, we observe an average Tobin's Q of 1.92. $\mathrm{HI}$ and $\mathrm{HI}^{2}$ are the industry (four-digit Standard Industrial Code [SIC]) sales Herfindahl index and squared Herfindahl index, respectively. These variables capture the competitive environment in which the firm operates. We also report various measures of capital expenditures and cash on hand as the financial health of the company may impact innovative efficiency.

We present several governance measures to control for possible managerial entrenchment motivations for spending on diversity policies. If a firm has poor governance and/or entrenched management, then pursing more diversity may be a vanity cause for the CEO and not a valuecreating proposition. These variables are presented in Table II, Panel C. For the average firm, insider ownership of top five executives is only $2.6 \%$ of shares. Equity/Pay is the proportion of the top five executives' compensation that is in the form of equity awards. This simple measure is a proxy for alignment of incentives. G-Index is the Gompers et al. (2003) governance index, defined as the sum of 24 anti-takeover provisions. A higher number represents weaker corporate governance - that is, less shareholder rights and more CEO power. The BCF-Index is the Bebchuck et al. (2009) entrenchment index, which consists of the six most effective antitakeover measures. Finally, we also include board size and the percentage of independents on the board. Full definitions of all variables used in the analysis are presented in the Appendix.

Table II, Panel D provides the mean and median values of the product announcements and net diversity strengths by Fama and French (1997) 48 industries. As would be expected, we see substantial variation by industry. Most striking from this table is the wide distribution of new product announcement across these industry groups. "Chips"-Electronic Equipment and "LabEq" have the highest number of new product announcements, with both more than 11 per 
firm per year. Next in order of announcement frequency are Precious Metals, Business Supplies, and Personal Services. Clearly, while tech firms have frequent product announcements, such activity is found across a wide range of industries, and these results show that innovation is not a subject merely of interest to Silicon Valley or biotech firms but is a pervasive force across the economy. We will, however, explicitly control for California-based firms in our later analysis. DIV also exhibits considerable variations across industries. Specifically, industries that favor pro-diversity policies the most include Candy and Soda, Tobacco Products, Personal Services, and Electronic Equipment. Those industries with the lowest net DIV measures are Mining, Defense, and Precious Metals.

\section{Results and Analysis for New Product Announcements}

In this section, we examine the effects of net diversity strengths on innovative efficiency based on the new product announcement data. We present the results of our main tests that include the baseline regressions with firm fixed effects, Granger causality tests to control for endogeneity, and subsample analyses excluding California firms to test for a "Silicon Valley" effect. We explore the underlying mechanism by conducting additional analyses based on various subsamples and, finally, examine the effect of diversity policies and innovation on firm value.

\section{A. Research Design}

To test the effects of pro-diversity policies on corporate innovative efficiency, we employ the following multivariate regression analysis:

$$
I E_{\text {Prod }, i, t+1}=\beta_{1} D I V_{i, t}+\beta_{2} X_{i, t}+\gamma_{i}+\delta_{t}+\varepsilon_{i, t+1}
$$


where $I E_{\text {Prod,i,t+l }}$ is either $\operatorname{Ln}\left(1+\operatorname{Prod}_{i, t+1}\right)$ or $\operatorname{Ln}\left(1+\operatorname{Prod}_{i, t+1}\right) /\left(1+R \& D_{i, t}\right), \operatorname{Prod}_{i, t+1}$ is the number of new product announcements made by firm $i$ in year $t+1$ and $R \& D_{i, t}$ is the research and development expense in the prior year, $D I V_{i, t}$ represents the measures related to diversity that we construct for firm $i$ in year $t, X_{i, t}$ contains control variables shown in prior literature to affect corporate innovation, $\delta_{t}$ is year fixed effects, and $\gamma_{i}$ is firm fixed effects. ${ }^{8}$ Following Atanassov (2013) and Chemmanur and Tian (2014), we include firm fixed effects to test how the variation of diversity-related policies within a firm is related to future variation in innovative efficiency or output. In addition, firm fixed effects can mitigate this endogeneity concern arising from unobservable, firm-specific, time-invariant, omitted variables. In addition, we report $t$-statistics based on standard errors adjusted by the Huber-While sandwich estimate of variances and clustered at the firm level.

\section{B. Diversity and New Product Announcements}

In Table III, we examine the impact of diversity on innovative output and efficiency as measured by new product announcements. The columns of the table present dependent variables: the number of annual product announcements and the number of announcements divided by R\&D expense. In each of these regressions, we find that diversity (DIV) is positively related to the measures of both innovation output and innovative efficiency, suggesting that pro-diversity policies may enhance innovative efficiency, ultimately leading to increased productivity or

\footnotetext{
${ }^{8}$ To ensure that industry effects do not drive our results, we also perform regression analyses using industry meanadjusted values for all variables in the regressions, where industry is defined as Fama-French 12 industry classifications. We also use the raw variables and include industry dummies in the regressions. Our findings remain qualitatively unchanged.
} 
innovation output. ${ }^{9}$ In these regressions, other variables might affect innovation. For example, we control for size, R\&D, and capital expenditures, as greater investment may lead to higher innovative efficiency—perhaps through economies of scale. ${ }^{10} \mathrm{We}$ also control for profitability, leverage, and cash, as firms with more resources and less risky cash flows may be able to provide more consistent $\mathrm{R} \& \mathrm{D}$ funding through time. We control for the number of employees in the firm with the variable $\operatorname{Ln}($ Sales/Employees) — the intuition being that firms with more employees may have a vested interest in treating their workers more favorably. Alternatively, firms with few employees may have most of their intellectual capital concentrated in a relatively small number of individuals that will motivate the firm to treat these employees well. We are agnostic about the sign of this variable, but in Table III regressions, it is not significant.

We control for Tobin's Q and find a positive relation between Q and innovative efficiency. This result is consistent with the notion that higher growth firms are likely to be more efficient innovators.

We control for a range of the strength of the firm's corporate governance. These variables include the percentage of shares owned by insiders, equity compensation structure, the G-Index, the BCF-Index, board size, and board independence, as defined in the Appendix. We find board independence is positively related to future innovative efficiency.

In terms of economic significance, the coefficient on DIV of 0.0239 implies that if a firm made significant improvements in its diversity level, say by increasing DIV by 7 points, the

\footnotetext{
${ }^{9}$ In untabulated tests, we do not find consistent effects of DIV on innovation input including R\&D-to-assets and R\&D-to-sales ratio. This finding is consistent with pro-diversity policies altering future innovation output via their impact on innovation efficiency rather than on innovation input.

${ }^{10}$ Note that current $R \& D$ is the denominator of our dependent variable, thus rendering an ambiguous coefficient on R\&D: on the one hand, greater R\&D should lead to greater innovation outcome (as confirmed in the first column when our dependent variable is innovative output) everything else equal; on the other hand, greater R\&D results in lower innovative efficiency measure simply due to the artificial effect that R\&D enters the denominator.
} 
average firm will see about two additional new product announcements over a 10 -year period. ${ }^{11}$ Clearly, just adding 1 point to DIV (i.e., by perhaps adding policies to encourage work-life benefits) is unlikely to have an instant impact on new product development. But a sustained effort to improve diversity across the organization will, in time, be rewarded with greater innovation.

These results provide preliminary support for our hypothesis - that pro-diversity policies are positively related to a firm's innovative efficiency. However, concerns remain, not least of which is the impact of endogeneity on our results. The next sections attempt to tackle this issue.

\section{Addressing Causality Round One: Granger Causality}

In Table IV, we examine the direction of causality between diversity and innovative efficiency using Granger causality regressions. Panel A regresses the change in new product announcements on the lagged change in diversity policies. In both models, we find a positive and significant coefficient. In Panel B, we reverse the model and regress the change in diversity on the lagged change in product announcements. Panel B shows that neither of the regression coefficients on the change in new product innovative efficiency measures are significant. These results are consistent with diversity Granger causing innovative efficiency but not the other way around, thus lending further credence to our conclusion.

\section{Addressing Causality Round Two: 2008 Financial Crisis}

In this section, we examine the impact of an economic downturn, in particular the 2008 financial crisis period on the relation between diversity policies and innovation. The purpose of

${ }^{11} \Delta \operatorname{Prod}=\left[e^{0.0239 \times 7}\right] \times 10=1.821$ 
the test is twofold. First, this test enables us to investigate whether firms with more pro-diversity policies are better able to recover from an economic downturn, when the investors and economy at large suffer uncertainty and risk. Evidence from this test can further our understanding on the role of corporate diversity practices in affecting innovation. Second, the financial crisis analysis can serve as an identification strategy to address endogeneity issue. The exogenous shock of the 2008 financial crisis is not likely to induce changes in the firms' diversity culture immediately, and thus we can potentially infer the causal effect of diversity on innovation during and following the crisis. ${ }^{12}$

In Table $\mathrm{V}$, we interact diversity with a crisis dummy that captures the two recessions in our sample: the 2001-2002 recession and the economic crisis of 2008-2009. ${ }^{13}$ In addition, we interact this dummy with all the other firm-specific variables in order to fully allow for different slope coefficients in response to the recessionary environment. The results show a positive and significant coefficient on this interaction term in both regressions. In untabulated tests, we interact only the crisis dummy with diversity but not the control variables; we find robust results. These results indicate that pro-diversity policies had a positive impact on the firm's ability to create new products even during and following the crisis, thereby helping the firms navigate the financial crisis. Our results are consistent with those of Lins, Servaes, and Tamayo (2017) who find that high corporate social responsibility firms performed better during the 2008 financial crisis.

While our tests do not fully uncover the mechanism at work here, a possible explanation is that a more diverse workforce is more resilient and able to respond to a shock to the economy.

\footnotetext{
${ }^{12}$ We thank the referee for suggesting this approach.

${ }^{13}$ Results are robust if we use alternative definitions for crisis period including (1) only years of 2001 and 2008 are considered the recession/crisis years, and (2) only years of 2008-2009 are considered, etc.
} 
Alternatively, firms with more pro-diversity policies are better able to retain and attract talented employees and get rewarded especially during the uncertain, risky crisis period when the trust in corporations, institutions, and the whole economy deteriorated.

\section{E. Location Effects: California versus Non-California Firms}

A valid concern surrounding our tests is that we may just be capturing a location-based effect. For example, firms that are located in a state that has both high levels of innovation and progressive policies may be driving a correlation rather than causation effect. The obvious candidate for such a state is California, home to Silicon Valley and progressive workplace policies. As a simple test of the potential California effect, we rerun our Table III tests for California only and all states except California. The results (presented in Table VI) show that the main findings of Table III appear to exist in both California firms and also non-California firms, although in the case of the Product Announcements scaled by R\&D for CA firms (first column) the effect of DIV is positive but insignificant. It therefore seems reasonable to conclude that our basic result is not being driven entirely by Silicon Valley firms.

\section{F. Investigating the Mechanism}

In this section, we attempt to uncover the mechanism through which workforce diversity impacts innovative efficiency. In particular, we analyze cross-sectional heterogeneity in the relation between diversity and innovative efficiency. We conjecture that the positive effect of diversity on innovative efficiency may behave differently depending on a firm's level of innovation, importance of intangibles or human capital including employees for a company's success, firms' growth options, proportion of women in the industry, leverage, free cash flow and 
financial constraints, and corporate governance.

\section{Importance of Innovative Efficiency}

If pro-diversity practices enhance innovative efficiency, we expect this positive effect to be more pronounced in firms with greater levels of innovation, where R\&D productivity and innovative efficiency are more critical for their long-term viability and success. Therefore, in Table VII, we create a partitioning variable — an indicator variable — that we interact with our diversity measure and include in the regression specifications. This partitioning variable represents those firms in the top (or bottom) quartile of firms on the specific measure being partitioned.

The first panel (Panel A) of Table VII shows the effect of this partitioning dummy on innovative efficiency. ${ }^{14} \operatorname{Ln}(1+$ Prod)_H equals one (zero) if a firm-year has $\operatorname{Ln}(1+$ Prod $)$ greater than (equal to) zero - that is, having at least one (none) annual new product announcement. ${ }^{15}$ For both models, the interaction term between diversity and $\operatorname{Ln}(1+\operatorname{Prod})_{-} H\left(\operatorname{Ln}(1+\operatorname{Prod})_{-} H^{*} D I V\right)$ is significant and positive, indicating that the impact of diversity is more pronounced for more innovative firms that actively and frequently engage in new product innovation.

\section{Asset Intangibility}

We condition our analysis on the importance of intangible assets, which often include human capital. If more favorable diversity treatment fosters innovation, then we expect this positive effect to be stronger for firms where human capital is more important relative to fixed assets. We use PPE/Assets as our proxy for the importance of fixed (tangible) assets, which is the

\footnotetext{
${ }^{14}$ We display only the variables of interest in the regression results to save space.

${ }^{15}$ Results are qualitatively similar if we use the innovative efficiency metric, $\operatorname{Ln}[(1+\operatorname{Prod}) /(1+R \& D)]$, to define the partitioning indicator variable.
} 
opposite of intangible assets such as employees: the higher PPE/Assets, the less crucial intangible assets (such as human capital) are to the success of the firm. We then create an indicator variable, PPE/Assets_H, which equals one (zero) if a firm has PPE/Assets in (below) the top quartile of the sample. Table VII, Panel B shows that the positive effect of diversity on innovative efficiency is weaker for firms that value intangible assets such as their (talented) employees less (negative and significant coefficient on PPE/Assets_H*DIV). In fact, for firms facing lower degree of human capital/employee importance, the effect of diversity on innovative efficiency is negative (the sum of coefficients on PPE/Assets_H, DIV, and the interaction term). This evidence suggests that not all investments in workforce diversity foster innovative efficiency: only those in firms where intangible assets including employees are most important for the performance of the firms.

\section{Growth Opportunities}

In Table VII, Panel C, we study the effect of diversity on innovation conditioning on firms' growth opportunities. If pro-diversity policies foster corporate innovation, we expect this effect to be stronger for firms with greater growth opportunities whose long-term success is more dependent on creativity and innovation. Following convention in prior literature, we use Tobin's Q to measure a firm's future growth opportunities. We then create an indicator variable, Q_L, which equals one (zero) if the q ratio of a firm is in (above) the bottom quartile of the sample. Panel C shows that indeed, the positive effect of pro-diversity policies substantially attenuates for firms with lower growth potential (the coefficient on the interaction term Q_L*DIV is significant and negative). In fact, the positive relation between DIV and innovation efficiency exists only in high-growth firms (the coefficient on DIV is significant and positive) but turns negative for firms with low-growth opportunities (the sum of coefficients on Q_L, DIV, and the 
interaction term is negative). This result is consistent with the notion that firms with greater growth opportunities have more to gain from promoting pro-diversity policies. This long-term orientation of firms is especially beneficial for innovation, as innovation is also a long-term investment.

\section{Proportion of Women Employed in the Industry}

Table VII, Panel D examines the partitioning effect of industry women ratio. We find a negative effect of diversity on innovative efficiency for firms in industries with a larger proportion of women. This result is consistent with the notion that firms in industries with fewer women in the labor force actually have more to gain from promoting pro-diversity policies, attracting and retaining more (talented) women (as well as other minority) employees. This benefit is in particular critical for innovation, as creativity often arises from diverse experiences, perspectives, and backgrounds.

\section{Financial Leverage, Free Cash Flow, and Financial Distress}

Table VII, Panels E and F show that for low leverage or high cash flow firms, diversity effects on innovation are stronger. To the extent that firms with low leverage or high cash flow might be less financially constrained, this finding is consistent with the following explanation. Maksimovic and Titman (1991) predict that firms that value highly their reputation for treating employees well will limit their use of debt. This is because a highly levered firm (or a firm with low free cash flows) might be more likely to face financial constraints and distress risk and therefore could have strong incentives to increase cash flows by reducing costs associated with employee benefits or deployment of pro-diversity policies. That is, the inability of a firm to maintain its reputation for treating its employees fairly could impose significant ex ante costs on 
its employees, and these costs can comprise an important part of indirect bankruptcy costs. Thus, according to the theoretical model of Maksimovic and Titman, firms with more favorable diversity policies are more likely to maintain low leverage or high cash flow. The low leverage and high cash flow may enable a firm to invest more in long-term, risky, intangible assets such as R\&D and innovation (which have low salvage values in bankruptcy) now that the firm faces less financial constraints and distress risk. This might contribute to the evidence in Panels E and F that more pro-diversity firms with low leverage and high cash flow are related to greater innovative efficiency. ${ }^{16}$

The evidence in Table VII, Panel F also suggests that pro-diversity policies do not represent managerial indulgence and the agency problem of free cash flow as described in Jensen (1986). Jensen argues that managers in firms with greater free cash flow may be more motivated to overinvest beyond the optimal level. Because firms with more free cash flow are likely to have more resources to spend in employee- or diversity-related benefits, managers in these firms are more motivated to treat their employees more generously (e.g., for personal or agency reasons) even if such an investment does not increase employee productivity or create shareholder value. Therefore, our result that pro-diversity policies enhance corporate innovation in high cash flow firms indicates that these policies are less likely to be subject to managerial agency motives. This is perhaps partly due to the fact that the implementation of diversity policies, unlike other types of employee treatment practices, does not require an explicit, large amount of monetary expenses.

${ }^{16}$ We thank the referee for suggesting these explanations. 


\section{Corporate Governance}

Finally, in Table VII, Panel G, we show the partitioning effect of corporate governance in terms of the BCF index. In these tests, diversity policies for firms with weaker governance (high BCF index) have a more negative effect on innovative efficiency. We think that this result in some ways disentangles the managerial indulgence effect (Masulis and Reza, 2015). Specifically, the evidence shows that only for firms that are well governed does building a pro-diversity culture drive innovative efficiency. In firms with weaker governance, investments in workforce diversity actually reduces innovative efficiency, presumably reflecting managerial indulgence and agency investments-for example, to boost managers' personal reputation or halo as socially responsible at the costs of shareholders.

\section{G. Diversity, New Product Announcements, and Firm Value}

In Table VIII, we consider the effect of diversity on firm value through its interaction with innovative efficiency measures (based on new product announcements). We now run the following regression model:

$$
Q_{i, t+1}=\beta_{1} I E_{\text {Prod }, i, t}+\beta_{2} D I V_{i, t-1}+\beta_{3} I E_{\text {Prod }, i, t} \times D I V_{i, t-1}+\beta_{4} X_{i, t-1}+\gamma_{i}+\delta_{t}+\varepsilon_{i, t+1}
$$

where $Q_{i, t+1}$ is the market-to-book ratio (Tobin's Q) measured in time $t+1$ for firm $i$ minus industry (the Fama-French 12 industries) median $Q^{17}, I E_{P r o d, i, t}$ is one of the two new product announcement measures at time $t$ for firm $i$-used as the dependent variable in the previous sections, $D I V_{i, t-1}$ is measured in time $t-1$ for firm $i$, and $X_{i, t-1}$ contains the full set of controls at time $t-1, \gamma_{i}$ is firm fixed effects, and $\delta_{t}$ is year fixed effects. All regressions contain firm and

\footnotetext{
${ }^{17}$ Using industry mean adjusted Q or raw Q as the dependent variable produces qualitatively similar results.
} 
year fixed effects. Importantly, controls include the firm's market-to-book ratio $(Q)$ at time $t-1$; but our results remain unchanged if lagged $Q$ is excluded from the control variables.

Table VIII shows that for a subsample of firm-years with at least one annual new product announcement (i.e., excluding firm-years with zero Prod), we observe a significant and positive coefficient on the interaction between DIV and the innovation efficiency measure in the second regression. ${ }^{18}$ This evidence is consistent with diversity having a positive effect on firm value, through its stimulating effect on the number of new product announcements per R\&D dollar spent. We note that this value effect is only salient for more innovative firms that actively and frequently engage in new product innovation. This evidence in fact lends more credence to our hypothesis and findings in that pro-diversity policies do not create value for all types of companies via stimulating innovative efficiency — they only do so for more innovative firms.

\section{Robustness Tests Using Patents and Citations}

As a robustness check on our main results, we test our hypothesis using patents and citations of patents as a measure of innovative efficiency. This approach allows us to conduct our analysis in a different time period, using a different dependent variable. As discussed earlier, we use four measures of innovative activity based on patents and citations. These are the patent variable scaled by the average patent count for the USPTO technology classification and then further scaled by the weighted time series of past $R \& D$ expenses. The second model scales patents by the HJT classification. The third and fourth models use future citations for a patent and measure the quality or impact of the patent.

\footnotetext{
${ }^{18}$ Results are insignificant for our full sample including firm-years with zero Prod.
} 
For both the USPTO and HJT classification-adjusted patents and citations, we compute innovation efficiency (IE) measures using the NBER patent and citation data as follows:

$$
\begin{aligned}
& I E_{P A T}=\frac{\text { aatents }_{i, t+1}}{R \& D_{i, t}+0.8 \times R \& D_{i, t-1}+0.6 \times R \& D_{i, t-2}+0.4 \times R \& D_{i, t-3}+0.2 \times R \& D_{i, t-4}} \\
& I E_{C I T E}=\frac{\text { Citations }_{i, t+1}}{R \& D_{i, t}+0.8 \times R \& D_{i, t-1}+0.6 \times R \& D_{i, t-2}+0.4 \times R \& D_{i, t-3}+0.2 \times R \& D_{i, t-4}}
\end{aligned}
$$

We then use $I E_{P A T}$ and $I E_{C I T E}$ as dependent variables in our tests and repeat the key tests performed on the product announcement data. Again, to control for any skewness, we take natural logarithms of one plus one of the four efficiency measures as our dependent variables.

\section{A. Baseline Regressions}

In Table IX, we present our results. Panel A presents the baseline regressions using the same setup as in Table III. Our variable of interest is diversity strengths net of diversity concerns $(D I V)$. All four regressions show a significant positive relation between innovative efficiency and $D I V$ - in other words, firms that have higher scores for diversity policies (net of concerns) see greater innovative efficiency in terms of patent production and also patent citations per R\&D dollar input. Recall that the dependent variables are adjusted for industry or technology class, and so these results should not be driven by a simple industry or technology effect. ${ }^{19}$ In the regression models, we explicitly control for all the variables included in the Table III. In the interest of space, we do not report these variable coefficients.

\section{B. Addressing Causality}

\footnotetext{
${ }^{19}$ In untabulated tests, we also examine the effects of DIV on patent and citation output measures without scaling them by $R \& D$ expenses, as well as on R\&D intensity (input) variables including R\&D-to-assets ratio, R\&D-to-sales ratio, and their respective industry-adjusted ratios. We find no significant or consistent effects of DIV on innovation output or R\&D input measures. It appears that DIV affects innovative efficiency rather than output or input only.
} 
In Table IX, Panels B-1 and B-2, we run Granger causality tests. In Panel B-1, we report the results of regressing changes in the various patent and citation innovative efficiency measures on lagged changes in DIV (the net diversity measure), along with lagged changes in the controls. In the first and fourth model (USPTO Patents and HJT Citations), the coefficient on the change in DIV is positive and significant. In the other two regressions, while the coefficient is positive, the statistical significance is below the $10 \%$ level. In Panel B-2 we repeat the setup but, this time, regress the changes in DIV on lagged changes in the innovative efficiency measures. In none of these regressions are the coefficients on changes in the innovation measures significant. These results support the conclusion that in at least two cases, DIV Granger causes innovative efficiency but not the other way around.

\section{Diversity, Innovative Efficiency, and Firm Value}

In Table IX, Panel C, we examine the impact of diversity on firm value (via its effect on innovative efficiency), using a model similar to regression Equation (2). The dependent variable is the firm's industry median adjusted market-to-book ratio (Tobin's Q) at time $t+1$. The innovative efficiency variables of interest are the four innovative efficiency measures at time $t$ : patents and citations per R\&D dollar, each bias-adjusted by the HJT and USPTO technology class and application year - the dependent variables used in the earlier analysis. The diversity measure and control variables are measured at year $t-1$. Our regression model is the following:

$$
Q_{i, t+1}=\beta_{1} I E_{i, t}+\beta_{2} D I V_{i, t-1}+\beta_{3} I E_{i, t} \times D I V_{i, t-1}+\beta_{4} X_{i, t-1}+\gamma_{i}+\delta_{t}+\varepsilon_{i, t+1}
$$

where all variables are defined the same as in Equation (2), except $I E_{i, t}$ is the natural logarithm of one plus one of the four patent and citation innovative efficiency measures in time $t$ for firm $i-$ used as the dependent variable in the previous sections. 
Table IX is arranged so that each column uses one of the four IE measures, but in each regression the dependent variable is the same: $Q_{t+1}$. The interaction between the IE measures and diversity captures the impact of diversity on firm value through its effects on innovative efficiency.

Consistent with our hypothesis, we find evidence that pro-diversity policies enhance firm value through its stimulating effect on innovative efficiency (positive and significant coefficients on the interaction terms for three out of four models). Interestingly, diversity policies do not add firm value other than through the effect of enhancing innovative efficiency (as indicated by the negative coefficients on $D I V)$.

\section{Conclusions}

We examine the impact that firms' diversity-focused policies have on innovation. We hypothesize that firms that promote greater workforce diversity will see more innovative efficiency as a culture of inclusion and diversity may serve to attract and motivate better talent from a larger and more diverse pool of job candidates. Diverse teams and workforces may also lead to more creative problem solving and innovation. Our alternative hypothesis states that at best, diversity policies amount to corporate green washing and will have no effect, and at worst, these activities are value destroying.

We measure diversity practices using the MSCI ESG STATS database. Innovative efficiency is measured using new product announcements and patents and citations scaled by research and development expense.

We find that firms that promote a pro-diversity workplace are rewarded by greater innovative efficiency. Our tests are robust to a wide battery of control variables as well as Granger causality tests. We control for R\&D intensity; a range of financial measures; industry, 
firm, and year fixed effects; and corporate governance effects. Including governance controls is important in case diversity policies are merely negative net present value indulgences by entrenched managers, a possibility not supported by the data. We also address potential concerns that our results are a "Silicon Valley" effect by explicitly excluding California-based firms and finding that our main results are unaffected.

Investigation of the underlying mechanism shows that the positive effect of employee treatment and pro-diversity policies on innovative efficiency is stronger in firms that are more innovative; firms that value more dearly intangibles or human capital such as (talented) employees; firms with greater growth options; firms in industries with fewer women; firms with lower leverage, more free cash flow, and less financial constraints; and firms with more effective corporate governance.

We find that pro-diversity policies increase future firm value via a positive effect on innovative efficiency, in particular for a subsample of more innovative firms that actively generate new products. Finally, pro-diversity policies and a culture of inclusion especially pay off during periods of economic downturns when investors, the financial markets, and the economy at large, suffer a severe crisis of trust. 


\section{References}

Aghion, P., J. van Reenen, and L. Zingales, 2013, "Innovation and Institutional Ownership," American Economic Review 103, 277-304.

Atanassov, J., 2013, "Do Hostile Takeovers Stifle Innovation? Evidence from Antitakeover Legislation and Corporate Patenting," Journal of Finance 68, 1097-1131.

Bae, K., J. Kang, and J. Wang, 2011, "Employee Treatment and Firm Leverage: A Test of the Stakeholder Theory of Capital Structure," Journal of Financial Economics 100, 130-153.

Bantel, K.A., and S.E. Jackson, 1989, “Top Management and Innovation in Banking: Does the Composition of the Top Team Make a Difference?" Strategic Management Journal 10, 107-124.

Bayus, B.L., G. Erickson, and R. Jacobson, 2003, "The Financial Rewards of New Product Introductions in the Personal Computer Industry," Management Science 49, 197-210.

Bebchuk, L., A. Cohen, and A. Ferrell, 2009, "What Matters in Corporate Governance?" Review of Financial Studies 22, 783-827.

Bereskin, F., T.L. Campbell, and P.H. Hsu, 2016, "Corporate Philanthropy, Research Networks, and Collaborative Innovation," Financial Management, 45, 175-206.

Blazovich, J.L., K.A. Cook, J.M. Huston, and W.R. Strawser, 2013, "Do Gay-Friendly Corporate Policies Enhance Firm Performance?” Working Paper.

Blundell, R., R. Griffith, and J. van Reenen, 1999, "Market Share, Market Value and Innovation in a Panel of British Firms," Review of Economic Studies 66, 529-554.

Brav, A., W. Jiang, S. Ma, and X. Tian, 2015, "Shareholder Power and Corporate Innovation: Evidence from Hedge Fund Activism," Working Paper.

Chan, L.K., J. Lakonishok, and T. Sougiannis, 2001, "The Stock Market Valuation of Research and Development Expenditures," The Journal of Finance 56, 2431-2456.

Chaney, P.K., T.M. Devinney, and R.S. Winer, 1991, "The Impact of New Product Introductions on the Market Value of Firms," Journal of Business 64, 573-610.

Chang, X., K. Fu, A. Low, and W. Zhang, 2015, "Non-Executive Employee Stock Options and Corporate Innovation," Journal of Financial Economics 115, 168-188.

Chemmanur T. and P. Fulghieri, 2014, "Entrepreneurial Finance and Innovation: An Introduction and Agenda for Future Research," Review of Financial Studies 27, 1-19. 
Chemmanur, T. and X. Tian, 2014. "Anti-Takeover Provisions, Innovation, and Firm Value: A Regression Discontinuity Analysis," Working Paper.

Cohn, J.B., U.G. Gurun, and R. Moussawi, 2016, "Micro-Level Value Creation under Managerial Short-Termism,” Working Paper.

Cornaggia, J., Y. Mao, X. Tian, and B. Wolfe, 2015, "Does Banking Competition Affect Corporate Innovation?” Journal of Financial Economics 115, 189-209.

Deng, Z., B. Lev, and F. Narin, 1999, "Science and Technology as Predictors of Stock Performance," Financial Analysts Journal 55, 20-32.

Ertugrul, M., 2013, "Employee-Friendly Acquirers and Acquisition Performance," Journal of Financial Research 36, 347-370.

Faems, D., B. Van Looy, and K. Debackere, 2005, "Interorganizational Collaboration and Innovation: Toward a Portfolio Approach," Journal of Product Innovation Management $22,238-250$.

Fama, E. and K. French, 1997, "Industry Costs of Equity," Journal of Financial Economics 43, 153-193.

Fang, V., X. Tian, and S. Tice, 2014, “Does Stock Liquidity Enhance or Impede Firm Innovation?” Journal of Finance 69, 2085-2125.

Fisman R., V.B. Nair, and G. Heal, 2005, “Corporate Social Responsibility: Doing Well by Doing Good," Working Paper.

Francis, B., I. Hasan, Y. Huang, and Z. Sharma, 2012, "Do Banks Value Innovation? Evidence from US Firms," Financial Management 41, 159-185.

Gao, H. and W. Zhang, 2015, “Does Workplace Discrimination Impede Innovation?” Working Paper.

Gompers, P., J. Ishii, and A. Metrick, 2003, “Corporate Governance and Equity Prices,” The Quarterly Journal of Economics 118, 107-156.

Granger, C.W.J., 1969, "Investigating Causal Relations by Econometric Models and CrossSpectral Methods," Econometrica 37, 424-438.

Griliches, Z., A. Pakes, and B. Hall, 1988, “The Value of Patents as Indicators of Inventive Activity," NBER Working Paper.

Gu, F., 2005, "Innovation, Future Earnings, and Market Efficiency," Journal of Accounting, Auditing and Finance 20, 385-418. 
Hall, B., 1999, “Innovation and Market Value,” NBER Working Paper.

Hall, B., A. Jaffe, and M. Trajtenberg, 2001, "The NBER Patent Citations Data File: Lessons, Insights and Methodological Tools," NBER Working Paper.

Hall, B., A. Jaffe, and M. Trajtenberg, 2005, "Market Value and Patent Citations," RAND Journal of Economics 36, 16-38.

He, J. and X. Tian, 2013, "The Dark Side of Analyst Coverage: The Case of Innovation," Journal of Financial Economics 109, 856-878.

Helmers, C., M. Patnam, and P.R. Rau, 2015, "Do Board Interlocks Increase Innovation? Evidence from Natural Experiments in India," Working Paper.

Hewlett, S.A., M. Marshall, and L. Sherbin, 2013, December, "How Diversity Can Drive Innovation," Harvard Business Review, Available at: https://hbr.org/2013/12/howdiversity-can-drive-innovation.

Hirshleifer, D., P.H. Hsu, and D. Li, 2013, "Innovative Efficiency and Stock Returns," Journal of Financial Economics 107, 632-654.

Hirshleifer, D., A. Low, and S.H. Teoh, 2012, "Are Overconfident CEOs Better Innovators?" Journal of Finance 67, 1457-1498.

Horwitz, S.K. and I.B. Horwitz, 2007, "The Effects of Team Diversity on Team Outcomes: A Meta-Analytic Review of Team Demography," Journal of Management 33, 987-1015.

Hsu, P., 2009, “Technological Innovations and Aggregate Risk Premiums," Journal of Financial Economics 94, 264-279.

Jensen, M.C., 1986, "Agency Costs of Free Cash Flow, Corporate Finance, and Takeovers," American Economic Review 76, 323-329.

Landier, A., V.B. Nair, and J. Wulf, 2009, "Trade-Offs in Staying Close: Corporate Decision Making and Geographic Dispersion," Review of Financial Studies 22, 1119-1148.

Lanjouw, J.O. and M. Schankerman, 2004, "Patent Quality and Research Productivity: Measuring Innovation with Multiple Indicators," The Economic Journal 114, 441-465.

Lev, B., B. Sarath, and T. Sougiannis, 2005, "R\&D Reporting Biases and Their Consequences," Contemporary Accounting Research 22, 977-1026.

Lins, K., H. Servaes, and A. Tamayo, 2016, "Social Capital, Trust, and Firm Performance: The Value of Corporate Social Responsibility during the Financial Crisis," Journal of Finance $72,1785-1824$. 
Maksimovic, V. and S. Titman, 1991, "Financial Policy and Reputation for Product Quality," Review of Financial Studies 4, 175-200.

Masulis, R. and S.W. Reza, 2015, “Agency Problems of Corporate Philanthropy,” Review of Financial Studies 28, 592-636.

Matolcsy, Z.P. and A. Wyatt, 2008, "The Association between Technological Conditions and the Market Value of Equity," The Accounting Review 83, 479-518.

Østergaard, C., B. Timmermans, and K. Kristinsson, 2011, "Does a Different View Create Something New? The Effect of Employee Diversity on Innovation," Research Policy 40, 500-509.

Pakes, A., 1985, “On Patents, R\&D and the Stock Market Rate of Return,” Journal of Political Economy 93, 390-409.

Pandit, S., C.E. Wasley, and T. Zach, 2011, “The Effect of Research and Development (R\&D) Inputs and Outputs on the Relation between the Uncertainty of Future Operating Performance and R\&D Expenditures," Journal of Accounting, Auditing and Finance 26, $121-144$.

Pauwels, K., J. Silva-Risso, S. Srinivasan, and D.M. Hanssens, 2004, "New Products, Sales Promotions, and Firm Value: The Case of the Automobile Industry," Journal of Marketing 68, 142-156.

Richard, O.C., 2000, "Racial Diversity, Business Strategy, and Firm Performance: A ResourceBased View," Academy of Management Journal 43, 164-177.

Sood, A. and G. Tellis, 2009, "Do Innovations Really Pay Off? Total Stock Market Returns to Innovation," Marketing Science 28, 442-456.

Srinivasan, S., K. Pauwels, J. Silva-Risso, and D. M. Hanssens, 2009, "Product Innovations, Advertising, and Stock Returns," Journal of Marketing 73, 24-43.

Talke, K., S. Salomo, and K. Rost, 2010, “How Top Management Team Diversity Affects Innovativeness and Performance via the Strategic Choice to Focus on Innovation Fields," Research Policy 39, 907-918

Trajtenberg, M., 1990, “A Penny for Your Quotes: Patent Citations and the Value of Innovations," RAND Journal of Economics 21, 172-187.

Turban, D.B. and D.W. Greening, 1997, “Corporate Social Performance and Organizational Attractiveness to Prospective Employees," Academy of Management Journal 40, 658672. 
Van der Vegt, G.S. and O. Janssen, 2003, "Joint Impact of Interdependence and Group Diversity on Innovation," Journal of Management 29, 729-751.

Wang, Y. and J. Zhao, 2015, "Hedge Funds and Corporate Innovation,” Financial Management 44, 353-385. 
Appendix. Variable Definitions

\begin{tabular}{|c|c|}
\hline Variable & Definition \\
\hline \multicolumn{2}{|l|}{ Panel A: Diversity Measures } \\
\hline A. $\mathrm{CEO}$ & $\begin{array}{l}\text { The company's chief executive officer is a woman or a member of a minority } \\
\text { group. }\end{array}$ \\
\hline B. Promotion & $\begin{array}{l}\text { The company has made notable progress in the promotion of women and } \\
\text { minorities, particularly to line positions with profit-and-loss responsibilities in } \\
\text { the corporation. }\end{array}$ \\
\hline C. Board of Directors & $\begin{array}{l}\text { Women, minorities, and/or the disabled hold four seats or more (with no } \\
\text { double counting) on the board of directors, or one-third or more of the board } \\
\text { seats if the board numbers fewer than } 12 \text {. }\end{array}$ \\
\hline D. Work-Life Benefits & $\begin{array}{l}\text { The company has outstanding employee benefits or other programs addressing } \\
\text { work-life concerns, e.g., childcare, elder care, or flextime. }\end{array}$ \\
\hline E. Women and Minority & The company does at least $5 \%$ of its subcontracting, or otherwise has a \\
\hline Contracting & $\begin{array}{l}\text { demonstrably strong record on purchasing or contracting, with women- and/or } \\
\text { minority-owned businesses. }\end{array}$ \\
\hline F. Employment of the Disabled & $\begin{array}{l}\text { The company has implemented innovative hiring programs; other innovative } \\
\text { human resource programs for the disabled, or otherwise has a superior } \\
\text { reputation as an employer of the disabled. }\end{array}$ \\
\hline G. Gay and Lesbian Policies & $\begin{array}{l}\text { The company has implemented notably progressive policies toward its gay and } \\
\text { lesbian employees. In particular, it provides benefits to the domestic partners } \\
\text { of its employees. }\end{array}$ \\
\hline H. Employment of & Factors affecting this evaluation include, but are not limited to, its effort to \\
\hline Underrepresented Groups & $\begin{array}{l}\text { recruit women and minorities, and its participation in multi stakeholder } \\
\text { diversity initiatives. }\end{array}$ \\
\hline X. Other Strength & $\begin{array}{l}\text { The company has made a notable commitment to diversity that is not covered } \\
\text { by other ESG ratings. }\end{array}$ \\
\hline
\end{tabular}

\section{Diversity Concerns}

A. Controversies

B. Nonrepresentation:

C. Board of Directors-Gender

D. Board of Directors-Minorities

X. Other Concern

The company has either paid substantial fines or civil penalties as a result of affirmative action controversies, or has otherwise been involved in major controversies related to affirmative action issues.

The company has no women on its board of directors or among its senior line managers.

This indicator identifies companies with no women on their board of directors. Split off from Diversity Concerns B.

This indicator identifies companies with no minorities on their board of directors.

The company is involved in diversity controversies not covered by other ESG ratings.

\begin{tabular}{|c|c|}
\hline Prod & Annual number of new product announcements for a firm in a calendar year \\
\hline Prod $_{\text {IndAdj }}$ & $\begin{array}{l}\text { Industry-adjusted Prod, defined as Prod divided by the industry average } \\
\text { number of new product announcements for the same year, where industry is } \\
\text { the Fama-French } 12 \text { industry }\end{array}$ \\
\hline $\operatorname{Ln}(1+$ Prod $)$ & Innovation output measure defined as the natural logarithm of one plus Prod \\
\hline $\operatorname{Ln}\left(1+\operatorname{Prod}_{\text {IndAdj }}\right)$ & $\begin{array}{l}\text { Innovation output measure defined as the natural logarithm of one plus } \\
\operatorname{Prod}_{\text {IndAdj }}\end{array}$ \\
\hline $\operatorname{Ln}[(1+\operatorname{Prod}) /(1+R \& D)]$ & Innovative efficiency defined as output variables divided by R\&D expense \\
\hline $\operatorname{Ln}\left[\left(1+\operatorname{Prod}_{\text {IndAdj }}\right) /(1+R \& D)\right]$ & $\begin{array}{l}\text { Innovative efficiency defined as industry mean adjusted output variables } \\
\text { divided by R\&D expense }\end{array}$ \\
\hline Patents & $\begin{array}{l}\text { The total number of patents filed for by (and ultimately granted to) firm } i \text { in } \\
\text { year } t\end{array}$ \\
\hline Patents_USPTO & $\begin{array}{l}\text { The total number of patents filed for by firm } i \text { in year } t \text { (and ultimately } \\
\text { granted) scaled by the average number of patents filed across all firms in the }\end{array}$ \\
\hline
\end{tabular}


Patents HJT

Citations

Citations_USPTO

Citations HJT

IEPAT

IEPAT_USPTO

IEPAT_HJT

$\mathrm{IE}_{\mathrm{CITE}}$

IE $_{\text {CITE_USPTO }}$

IE

same USPTO class and application year $t$

The total number of patents filed by firm $i$ in year $t$ (and ultimately granted) scaled by the average number of patents filed across all firms in the same HJT technology field and year $t$

The number of citations received on all patents applied for (and ultimately granted) in year $t$ for firm $i$

The number of citations received on all patents filed for (and ultimately granted) in year $t$ for firm $i$, where the number of citations is scaled by the total number of citations received for all patents filed in the same USPTO class with the same application year $t$

The number of citations received on all patents filed for (and ultimately granted) in year $t$ for firm $i$, where the number of citations is scaled by the total number of citations received for all patents filed in the same HJT technology field with the same application year $t$ Innovative efficiency for firm $i$ in year $t$, defined as

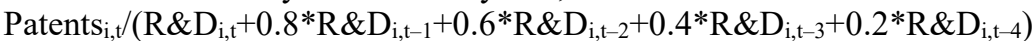
Innovative efficiency for firm $i$ in year $t$ adjusted for application year and

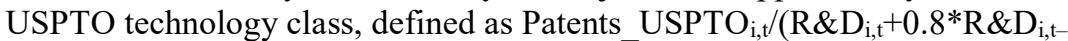
$\left.{ }_{1}+0.6 * \mathrm{R} \& \mathrm{D}_{\mathrm{i}, \mathrm{t}-2}+0.4 * \mathrm{R} \& \mathrm{D}_{\mathrm{i}, \mathrm{t}-3}+0.2 * \mathrm{R} \& \mathrm{D}_{\mathrm{i}, \mathrm{t}-4}\right)$

Innovative efficiency for firm $i$ in year $t$ adjusted for application year and HJT technology field, defined as Patents_HJT $\mathrm{i}_{\mathrm{i}, \mathrm{t}}\left(\mathrm{R} \& \mathrm{D}_{\mathrm{i}, \mathrm{t}}+0.8 * \mathrm{R} \& \mathrm{D}_{\mathrm{i}, \mathrm{t}-1}+0.6 * \mathrm{R} \& \mathrm{D}_{\mathrm{i}, \mathrm{t}-}\right.$ $\left.{ }_{2}+0.4 * \mathrm{R} \& \mathrm{D}_{\mathrm{i}, \mathrm{t}-3}+0.2 * \mathrm{R} \& \mathrm{D}_{\mathrm{i}, \mathrm{t}-4}\right)$

Innovative efficiency for firm $i$ in year $t$, defined as Citations $_{\mathrm{i}, \mathrm{t}} /\left(\mathrm{R}_{\mathrm{CD}_{\mathrm{i}, \mathrm{t}}}+0.8 * \mathrm{R} \& \mathrm{D}_{\mathrm{i}, \mathrm{t}-1}+0.6 * \mathrm{R} \& \mathrm{D}_{\mathrm{i}, \mathrm{t}-2}+0.4 * \mathrm{R} \& \mathrm{D}_{\mathrm{i}, \mathrm{t}-3}+0.2 * \mathrm{R} \& \mathrm{D}_{\mathrm{i}, \mathrm{t}-4}\right)$ Innovative efficiency for firm $i$ in year $t$ adjusted for application year and USPTO technology class, defined as Citations_USPTO ${ }_{\mathrm{i}, t} /\left(\mathrm{R}_{-} \& \mathrm{D}_{\mathrm{i}, \mathrm{t}}+0.8 * \mathrm{R} \& \mathrm{D}_{\mathrm{i}, \mathrm{t}-}\right.$ $\left.{ }_{1}+0.6 * \mathrm{R} \& \mathrm{D}_{\mathrm{i}, \mathrm{t}-2}+0.4 * \mathrm{R} \& \mathrm{D}_{\mathrm{i}, \mathrm{t}-3}+0.2 * \mathrm{R} \& \mathrm{D}_{\mathrm{i}, \mathrm{t}-4}\right)$

Innovative efficiency for firm $i$ in year $t$ adjusted for application year and HJT technology filed, defined as Citations $\mathrm{HJT}_{\mathrm{i}, \mathrm{t}} /\left(\mathrm{R} \& \mathrm{D}_{\mathrm{i}, \mathrm{t}}+0.8 * \mathrm{R} \& \mathrm{D}_{\mathrm{i}, \mathrm{t}-}\right.$ ${ }_{1}+0.6 * \mathrm{R} \& \mathrm{D}_{\mathrm{i}, \mathrm{t}-2}+0.4 * \mathrm{R} \& \mathrm{D}_{\mathrm{i}, \mathrm{t}-3}+0.2 * \mathrm{R} \& \mathrm{D}_{\mathrm{i}, \mathrm{t}-4)}$

\begin{tabular}{|c|c|}
\hline Ln (MV) & Natural logarithm of market value of equity [\#25*\#199] \\
\hline Ln (Assets) & Natural logarithm of total assets $[\# 6]$ \\
\hline Ln (Sales) & Natural logarithm of total sales [\#12] \\
\hline $\mathrm{R} \& \mathrm{D} /$ Assets & Research and development expenditure over assets [\#46/\#6] \\
\hline Ln (Sales/Employee) & $\begin{array}{l}\text { Natural logarithm of total sales [\#12] scaled by the total number of employees } \\
\text { [\#39] }\end{array}$ \\
\hline CapX/Assets & Capital expenditure over assets [\#128/\#6] \\
\hline PPE/Assets & Net property, plant, and equipment to assets [\#8/\#6] \\
\hline ROA & $\begin{array}{l}\text { Return on assets defined as operating income before depreciation over assets } \\
{[\# 13 / \# 6]}\end{array}$ \\
\hline Debt/Assets & Book value of debts over book value of total assets $[(\# 34+\# 9) / \# 6]$ \\
\hline Cash/Assets & Cash to assets $[\# 1 / \# 6]$ \\
\hline Q & $\begin{array}{l}\text { Tobin's q defined as market value of assets over book value of assets [(\#6- } \\
\left.\left.\# 60+\operatorname{abs}\left(\# 25^{*} \# 199\right)\right) / \# 6\right]\end{array}$ \\
\hline SICC Herfindahl & Herfindahl index of sales of four-digit SIC industry where the firm belongs \\
\hline SICC Herfindahl ${ }^{2}$ & The square of HI \\
\hline Ln (Age) & $\begin{array}{l}\text { Natural logarithm of one plus firm age, measured as the number of years listed } \\
\text { on CRSP }\end{array}$ \\
\hline Insider Ownership & The percentage of the company's shares owned by top five executives \\
\hline Equity/Total Pay & $\begin{array}{l}\text { The total value of new restricted stocks and stock options granted as a } \\
\text { percentage of annual total pay for the top five executives }\end{array}$ \\
\hline G-Index & $\begin{array}{l}\text { The anti-takeover provisions index from Gompers et al. (2003). For years } \\
\text { beyond 2006, we apply the } 2006 \text { G-Index levels as the ISS (formerly Risk } \\
\text { Metrics) does not track the aggregate G-Index subsequent to } 2006\end{array}$ \\
\hline BCF-Index & An index based on six anti-takeover provisions as in Bebchuk et al. (2009), \\
\hline
\end{tabular}


including staggered board, poison pill, supermajority to approve mergers, limits to amend bylaws, limits to amend charters, and golden parachutes

Board Size

The number of directors on the board.

Board Independence

The percentage of independent directors, defined as the number of independent directors over board size 
Table I. Summary Statistics for Diversity Measures

This table reports the diversity-related measures over 2000-2013. _str is strength,_con is concern. Each measure is either scored as a 0 or 1 . DIV is the net diversity strengths defined as the total diversity strengths subtracted by total diversity concerns. All except binary variables are winsorized at the upper and lower $1 \%$ levels.

\begin{tabular}{|c|c|c|c|c|c|}
\hline & & Observations & Mean & S.D. & Median \\
\hline DIV str A & CEO Is Women/Minority & 8,395 & 0.037 & 0.189 & 0.000 \\
\hline DIV_str_B & Promotion of Women/Minorities & 9,239 & 0.199 & 0.399 & 0.000 \\
\hline $\mathrm{DIV}^{-} \mathrm{str} \mathrm{C}$ & Board of Directors Has Minorities & 10,807 & 0.08 & 0.272 & 0.000 \\
\hline $\mathrm{DIV}^{-} \mathrm{str}^{-} \mathrm{D}$ & Work-Life Benefits & 9,021 & 0.076 & 0.265 & 0.000 \\
\hline $\mathrm{DIV}^{-} \mathrm{str}^{-} \mathrm{E}$ & Women \& Minority Contracting & 9,571 & 0.068 & 0.252 & 0.000 \\
\hline DIV_str_F & Employment of the Disabled & 8,395 & 0.02 & 0.141 & 0.000 \\
\hline DIV_str_G & Gay \& Lesbian Policies & 9,239 & 0.187 & 0.39 & 0.000 \\
\hline $\mathrm{DIV}^{-} \mathrm{str}^{-} \mathrm{H}$ & Employment of Underrepresented Groups & 1,600 & 0.199 & 0.400 & 0.000 \\
\hline DIV_str_X & Other Strengths & 10,066 & 0.008 & 0.088 & 0.000 \\
\hline DIV_con_A & Controversies & 11,643 & 0.072 & 0.259 & 0.000 \\
\hline $\mathrm{DIV}^{-} \operatorname{con} \mathrm{B}$ & Nonrepresentation Concern & 10,066 & 0.359 & 0.48 & 0.000 \\
\hline $\mathrm{DIV}^{-} \operatorname{con}^{-} \mathrm{C}$ & Board of Directors - Gender & 3,248 & 0.424 & 0.494 & 0.000 \\
\hline DIV_con_D & Board of Directors-Minorities & 1,577 & 0.201 & 0.401 & 0.000 \\
\hline $\mathrm{DIV} \operatorname{con} \mathrm{X}$ & Other Concerns & 8,395 & 0.007 & 0.086 & 0.000 \\
\hline DIV & $\begin{array}{l}\text { Net strengths }=\text { total diversity strengths minus } \\
\text { total diversity concerns }\end{array}$ & 11,643 & 0.038 & 1.358 & 0.000 \\
\hline
\end{tabular}


Table II. Summary Statistics for Innovative Efficiency Measures and Firm Characteristics

Panel A reports the innovative efficiency metrics. New product announcement innovative metrics include 11,643 firmyear observations over 2001-2014. Patent innovation metrics contain 3,249 observations over 1996-2006. Panels B and $\mathrm{C}$ report firm characteristics and governance measures respectively over 2000-2013. Full variable definitions are contained in the Appendix. Panel D reports the distribution of the new product innovative metrics data and the net diversity strengths (DIV) across the Fama and French 48 industry classifications. The number of observations varies by industry. All except binary variables are winsorized at the upper and lower $1 \%$ levels.

\begin{tabular}{|c|c|c|c|c|c|}
\hline Panel A. Innovative Efficiency & Mean & S.D. & Min & Median & Max \\
\hline $\begin{array}{l}\text { New Product Announcements } \\
\text { Annual \# of new product announcements } \\
\text { (Prod) }\end{array}$ & 3.831 & 7.517 & 0.000 & 0.000 & 30.000 \\
\hline $\operatorname{Ln}(1+$ Prod $)$ & 0.828 & 1.087 & 0.000 & 0.000 & 3.434 \\
\hline $\operatorname{Ln}[(1+\operatorname{Prod}) /(1+\operatorname{R} \& D)]$ & -1.264 & 1.893 & -4.931 & 0.000 & 1.946 \\
\hline \multicolumn{6}{|l|}{ Patents and Citations } \\
\hline Patents & 30.911 & 55.130 & 0.000 & 3.000 & 184.000 \\
\hline Patents_USPTO & 7.698 & 12.682 & 0.000 & 1.054 & 41.171 \\
\hline Patents_HJT & 2.228 & 3.744 & 0.000 & 0.335 & 12.298 \\
\hline Citations & 67.687 & 152.329 & 0.000 & 0.000 & 543.000 \\
\hline Citations_USPTO & 34.648 & 64.745 & 0.000 & 0.000 & 212.780 \\
\hline Citations_HJT & 35.059 & 66.715 & 0.000 & 0.000 & 222.550 \\
\hline IEPAT_USPTO & 0.020 & 0.055 & 0.000 & 0.004 & 2.310 \\
\hline IE & 0.005 & 0.014 & 0.000 & 0.001 & 0.514 \\
\hline IE $_{\text {CITE_USPTO }}$ & 0.074 & 0.323 & 0.000 & 0.000 & 16.109 \\
\hline IE $E_{\text {CITE_HJT }}$ & 0.072 & 0.186 & 0.000 & 0.000 & 3.159 \\
\hline Panel B. Firm Characteristics & Mean & S.D. & Min & Median & Max \\
\hline MV (\$million) & $9,915.675$ & $27,000.000$ & 10.942 & $2,565.004$ & $500,000.000$ \\
\hline Sales (\$million) & $7,755.819$ & $22,000.000$ & 14.127 & $2,136.212$ & $470,000.000$ \\
\hline Assets (\$million) & $8,978.073$ & $23,000.000$ & 52.242 & $2,412.499$ & $480,000.000$ \\
\hline R\&D (\$million) & 172.807 & 722.248 & 0.000 & 0.000 & $12,000.000$ \\
\hline $\mathrm{R} \& \mathrm{D} /$ Assets & 0.027 & 0.047 & 0.000 & 0.000 & 0.341 \\
\hline CapX/Assets & 0.051 & 0.048 & 0.001 & 0.037 & 0.329 \\
\hline PPE/Assets & 0.291 & 0.229 & 0.002 & 0.218 & 0.883 \\
\hline ROA & 0.141 & 0.084 & -0.644 & 0.134 & 0.432 \\
\hline Leverage & 0.223 & 0.166 & 0.000 & 0.220 & 0.927 \\
\hline Cash/Assets & 0.141 & 0.155 & 0.001 & 0.082 & 0.911 \\
\hline $\mathrm{Q}$ & 1.919 & 1.113 & 0.752 & 1.569 & 8.901 \\
\hline $\mathrm{HI}$ & 0.244 & 0.198 & 0.032 & 0.192 & 1.000 \\
\hline Age & 29.360 & 20.559 & 1.000 & 23.000 & 88.000 \\
\hline Panel C. Governance Measures & Mean & S.D. & Min & Median & Max \\
\hline Insider Ownership & 0.026 & 0.059 & 0.000 & 0.006 & 0.393 \\
\hline Equity/Pay & 0.201 & 0.273 & 0.000 & 0.000 & 0.875 \\
\hline G Index & 9.357 & 2.458 & 4.000 & 9.000 & 15.000 \\
\hline BCF Index & 1.547 & 1.073 & 0.000 & 2.000 & 4.000 \\
\hline Board Independence & 0.746 & 0.141 & 0.308 & 0.778 & 0.923 \\
\hline
\end{tabular}


Table II (Continued)

\begin{tabular}{|c|c|c|c|c|c|}
\hline \multirow{2}{*}{$\begin{array}{l}\text { Panel D. New Product Innovation and DIV by Industry } \\
\text { (Fama-French } 48 \text { Industry) }\end{array}$} & \multirow[b]{2}{*}{$\mathbf{N}$} & \multicolumn{2}{|c|}{ Prod } & \multicolumn{2}{|c|}{ DIV } \\
\hline & & Mean & Median & Mean & Median \\
\hline 1 Agric: Agriculture & 25 & 1.760 & 0.000 & 0.240 & -1.000 \\
\hline 2 Food: Food Products & 304 & 1.539 & 0.000 & 0.095 & 0.000 \\
\hline 3 Soda: Candy \& Soda & 34 & 0.441 & 0.000 & 0.765 & 1.000 \\
\hline 4 Beer: Beer \& Liquor & 58 & 3.914 & 2.000 & 0.207 & 0.000 \\
\hline 5 Smoke: Tobacco Products & 31 & 0.161 & 0.000 & 0.645 & 0.000 \\
\hline 6 Toys: Recreation & 78 & 4.538 & 3.000 & 0.192 & 0.000 \\
\hline 7 Fun: Entertainment & 88 & 1.375 & 0.000 & 0.318 & 0.000 \\
\hline 9 Hshld: Consumer Goods & 84 & 6.286 & 2.000 & 0.143 & 0.000 \\
\hline 10 Clths: Apparel & 114 & 0.430 & 0.000 & 0.333 & 0.000 \\
\hline 11 Hlth: Healthcare & 232 & 0.642 & 0.000 & 0.129 & 0.000 \\
\hline 12 MedEq: Medical Equipment & 336 & 5.792 & 2.000 & 0.107 & 0.000 \\
\hline 16 Txtls: Textiles & 30 & 0.633 & 0.000 & 0.333 & 0.000 \\
\hline 17 BldMt: Construction Materials & 1,551 & 3.584 & 1.000 & 0.197 & 0.000 \\
\hline 18 Cnstr: Construction & 209 & 0.766 & 0.000 & -0.239 & 0.000 \\
\hline 19 Steel: Steel Works, Etc. & 212 & 0.495 & 0.000 & -0.524 & -0.500 \\
\hline 20 FabPr: Fabricated Products & 23 & 0.000 & 0.000 & -0.609 & -1.000 \\
\hline 21 Mach: Machinery & 538 & 1.725 & 0.000 & -0.299 & 0.000 \\
\hline 22 ElcEq: Electrical Equipment & 176 & 2.432 & 0.000 & -0.386 & 0.000 \\
\hline 23 Autos: Automobiles and Trucks & 51 & 0.941 & 0.000 & -0.490 & 0.000 \\
\hline 24 Aero: Aircraft & 208 & 3.240 & 1.000 & -0.216 & 0.000 \\
\hline 25 Ships: Shipbuilding, Railroad Equipment & 107 & 4.570 & 0.000 & -0.393 & -1.000 \\
\hline 26 Guns: Defense & 25 & 0.320 & 0.000 & -0.800 & -1.000 \\
\hline 27 Gold: Precious Metals & 47 & 8.128 & 2.000 & -0.723 & -1.000 \\
\hline 28 Mines: Non-Metallic \& Industrial Metal Mining & 15 & 0.533 & 0.000 & -1.000 & -1.000 \\
\hline 29 Coal: Coal & 62 & 0.290 & 0.000 & -0.081 & 0.000 \\
\hline 30 Oil: Petroleum and Natural Gas & 27 & 0.370 & 0.000 & -0.185 & 0.000 \\
\hline 31 Util: Utilities & 514 & 1.109 & 0.000 & -0.574 & -1.000 \\
\hline 32 Telcm: Communication & 950 & 0.140 & 0.000 & -0.248 & 0.000 \\
\hline 33 PerSv: Personal Services & 206 & 6.922 & 1.000 & 1.024 & 1.000 \\
\hline 34 BusSv: Business Services & 113 & 0.159 & 0.000 & -0.027 & 0.000 \\
\hline 35 Comps: Computers & 1,199 & 6.642 & 2.000 & 0.280 & 0.000 \\
\hline 36 Chips: Electronic Equipment & 420 & 12.845 & 11.000 & 0.517 & 0.000 \\
\hline 37 LabEq: Measuring and Control Equipment & 874 & 12.531 & 9.000 & -0.192 & 0.000 \\
\hline 38 Paper: Business Supplies & 299 & 6.873 & 3.000 & -0.027 & 0.000 \\
\hline 39 Boxes: Shipping Containers & 240 & 2.467 & 0.000 & -0.142 & 0.000 \\
\hline 40 Trans: Transportation & 68 & 0.632 & 0.000 & -0.412 & 0.000 \\
\hline 41 Whlsl: Wholesale & 365 & 2.208 & 0.000 & -0.230 & 0.000 \\
\hline 42 Rtail: Retail & 429 & 1.242 & 0.000 & -0.037 & 0.000 \\
\hline 43 Meals: Restaurants, Hotels, Motels & 943 & 0.928 & 0.000 & 0.468 & 0.000 \\
\hline 44 Banks: Banking & 257 & 1.525 & 0.000 & 0.385 & 0.000 \\
\hline 45 Insur: Insurance & 4 & 0.500 & 0.500 & 0.250 & 0.500 \\
\hline
\end{tabular}


46 RlEst: Real Estate

0.730

0.000

$\begin{array}{ll}0.514 & 0.000\end{array}$

48 Other: Almost Nothing

23

2.478

1.000

$-0.174 \quad 0.000$ 


\section{Table III. The Effect of Diversity on Product Innovation}

The dependent variables are natural logarithms of one plus the annual number of new product announcements, $\operatorname{Ln}[(1+$ Prod $)$, and of one plus the annual number of new product announcements divided by one plus $\mathrm{R} \& \mathrm{D}$ expenses, $\operatorname{Ln}[(1+\operatorname{Prod}) /(1+R \& D)]$. All regressions contain firm and year fixed effects. All except binary variables are winsorized at the upper and lower $1 \%$ levels. Full variable definitions are provided in the Appendix. $T$-statistics are reported in parentheses. Standard errors are adjusted based on the Huber-White sandwich estimate of variances and are clustered by firm. $* * *$ indicates significance at the $1 \%$ level, $* * 5 \%$, and $* 10 \%$.

\begin{tabular}{|c|c|c|}
\hline & $\operatorname{Ln}(1+$ Prod $)$ & $\operatorname{Ln}[(1+\operatorname{Prod}) /(1+R \& D)]$ \\
\hline DIV & $\begin{array}{l}0.0239 * * * \\
(3.49)\end{array}$ & $\begin{array}{l}0.0187^{* *} \\
(2.34)\end{array}$ \\
\hline $\operatorname{Ln}(\mathrm{mv})$ & $\begin{array}{l}0.0519 * * \\
(2.44)\end{array}$ & $\begin{array}{l}-0.2173^{* * *} \\
(-7.04)\end{array}$ \\
\hline $\mathrm{R} \& \mathrm{D} /$ Assets & $\begin{array}{l}1.2635^{* * *} \\
(2.76)\end{array}$ & $\begin{array}{l}-7.0301 * * * \\
(-9.49)\end{array}$ \\
\hline Ln(Sales/Employee) & $\begin{array}{l}0.0355 \\
(0.95)\end{array}$ & $\begin{array}{l}0.0397 \\
(0.73)\end{array}$ \\
\hline CapX/Assets & $\begin{array}{l}-0.0047 \\
(-0.02)\end{array}$ & $\begin{array}{l}-0.2591 \\
(-0.90)\end{array}$ \\
\hline PPE/Assets & $\begin{array}{l}-0.4259 * * * \\
(-2.82)\end{array}$ & $\begin{array}{l}0.0706 \\
(0.34)\end{array}$ \\
\hline ROA & $\begin{array}{l}0.0606 \\
(0.43)\end{array}$ & $\begin{array}{l}-0.2133 \\
(-1.23)\end{array}$ \\
\hline Debt/Assets & $\begin{array}{l}0.1064 \\
(1.32)\end{array}$ & $\begin{array}{l}-0.3174 * * * \\
(-3.07)\end{array}$ \\
\hline Cash/Assets & $\begin{array}{l}-0.0191 \\
(-0.18)\end{array}$ & $\begin{array}{l}0.3464 * * * \\
(2.72)\end{array}$ \\
\hline Q & $\begin{array}{l}-0.0939 * * * \\
(-6.18)\end{array}$ & $\begin{array}{l}0.0729 * * * \\
(3.98)\end{array}$ \\
\hline SICC Herfindahl & $\begin{array}{l}0.3351 \\
(1.29)\end{array}$ & $\begin{array}{l}0.3405 \\
(0.91)\end{array}$ \\
\hline SICC Herfindahl ${ }^{2}$ & $\begin{array}{l}-0.4275^{*} \\
(-1.81)\end{array}$ & $\begin{array}{l}-0.5010 \\
(-1.34)\end{array}$ \\
\hline Ln(Age) & $\begin{array}{l}-0.1166^{*} \\
(-1.71)\end{array}$ & $\begin{array}{l}-0.0760 \\
(-0.85)\end{array}$ \\
\hline Insider Ownership & $\begin{array}{l}-0.0872 \\
(-0.35)\end{array}$ & $\begin{array}{l}0.0284 \\
(0.09)\end{array}$ \\
\hline Equity/Total Pay & $\begin{array}{l}-0.0074 \\
(-0.19)\end{array}$ & $\begin{array}{l}0.0961 * \\
(1.92)\end{array}$ \\
\hline G Index & $\begin{array}{l}0.0283 \\
(1.27)\end{array}$ & $\begin{array}{l}-0.0210 \\
(-0.85)\end{array}$ \\
\hline BCF Index & $\begin{array}{l}-0.0360 \\
(-0.93)\end{array}$ & $\begin{array}{l}0.0025 \\
(0.04)\end{array}$ \\
\hline Board Independence & $\begin{array}{l}0.1005 \\
(1.32)\end{array}$ & $\begin{array}{l}0.2300^{* *} \\
(2.31)\end{array}$ \\
\hline Board Size & $\begin{array}{l}0.0046 \\
(0.75)\end{array}$ & $\begin{array}{l}0.0046 \\
(0.41)\end{array}$ \\
\hline Constant & $\begin{array}{l}0.5288 \\
(1.26)\end{array}$ & $\begin{array}{c}0.4941 \\
(0.97)\end{array}$ \\
\hline Observations & 11,636 & 11,636 \\
\hline R-squared & 0.156 & 0.104 \\
\hline Firm and Year FE & Yes & Yes \\
\hline
\end{tabular}




\section{Table IV. Addressing Causality: Change on Change Regressions Using Product Innovation}

Measures

In Panel $\mathrm{A}$, the dependent variables are changes in product innovative efficiency measures in year $t$. The independent variables are changes in net diversity strengths in year $t-1$, along with the changes in controls in year $t$ 1. Product innovative efficiency measures include the natural logarithms of one plus the annual number of new product announcements, $\operatorname{Ln}[(1+$ Prod $)$, and of one plus the annual number of new product announcements divided by one plus $\mathrm{R} \& \mathrm{D}$ expenses, $\operatorname{Ln}[(1+\operatorname{Prod}) /(1+R \& D)]$. In Panel $\mathrm{B}$, the dependent variables are changes in net diversity strengths in year $t$. The independent variables are changes in product innovative efficiency measures in year $t-1$, and changes in controls in year $t-1$. Constants are omitted in Panel A, and controls are included but omitted in Panel B for brevity. All regressions contain year fixed effects. All except binary variables are winsorized at the upper and lower $1 \%$ levels. Full variable definitions are provided in the Appendix. $T$-statistics are reported in parentheses. Standard errors are adjusted based on the Huber-White sandwich estimate of variances and are clustered by firm. $* * *$ indicates significance at the $1 \%$ level, ** $5 \%$, and $* 10 \%$.

\begin{tabular}{|c|c|c|}
\hline \multicolumn{3}{|c|}{$\begin{array}{l}\text { Panel A: Regressions of Change in Product Innovative Efficiency in Year } \mathrm{t} \text { on Change in Diversity in Year } \mathrm{t}- \\
\quad 1\end{array}$} \\
\hline Dep. Var. = & $\Delta \operatorname{Ln}\left(1+\operatorname{Prod}_{\mathrm{t}}\right.$ & $\Delta \operatorname{Ln}[(1+\operatorname{Prod}) /(1+R \& D)]_{\mathrm{t}}$ \\
\hline$\Delta \mathrm{DIV}_{\mathrm{t}-1}$ & $\begin{array}{l}0.0187 * * * \\
(3.24)\end{array}$ & $\begin{array}{l}0.0193 * * * \\
(3.14)\end{array}$ \\
\hline$\Delta \operatorname{Ln}(\mathrm{mv})_{\mathrm{t}-1}$ & $0.0628 * * *$ & $-0.0695 * * *$ \\
\hline & $(3.33)$ & $(-3.15)$ \\
\hline$\Delta \mathrm{R} \& \mathrm{D} /$ Assets $_{\mathrm{t}-1}$ & $\begin{array}{l}1.6662 * * * \\
(2.84)\end{array}$ & $\begin{array}{l}-7.8849 * * * \\
(-10.84)\end{array}$ \\
\hline$\Delta \mathrm{Ln}(\text { Sales/Employee })_{\mathrm{t}-1}$ & $\begin{array}{l}-0.0068 \\
(-0.18)\end{array}$ & $\begin{array}{l}-0.0333 \\
(-0.78)\end{array}$ \\
\hline$\Delta$ CapX/Assets $_{\mathrm{t}-1}$ & $\begin{array}{l}-0.1403 \\
(-0.63)\end{array}$ & $\begin{array}{l}-0.0933 \\
(-0.39)\end{array}$ \\
\hline$\Delta \mathrm{PPE} /$ Assets $_{\mathrm{t}-1}$ & $\begin{array}{l}0.0391 \\
(0.24)\end{array}$ & $\begin{array}{l}0.3086^{*} \\
(1.68)\end{array}$ \\
\hline$\Delta \mathrm{ROA}_{\mathrm{t}-1}$ & $\begin{array}{l}0.1430 \\
(1.07)\end{array}$ & $\begin{array}{l}0.1058 \\
(0.73)\end{array}$ \\
\hline$\Delta$ Debt/Assets $_{\mathrm{t}-1}$ & $\begin{array}{l}0.0731 \\
(0.88)\end{array}$ & $\begin{array}{l}-0.2354 * * \\
(-2.58)\end{array}$ \\
\hline 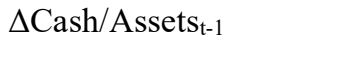 & $\begin{array}{l}0.0458 \\
(0.50)\end{array}$ & $\begin{array}{l}0.3345^{* * *} \\
(3.42)\end{array}$ \\
\hline$\Delta \mathrm{Q}_{\mathrm{t}-1}$ & $\begin{array}{l}-0.0583^{* * *} \\
(-4.53)\end{array}$ & $\begin{array}{l}0.0022 \\
(0.15)\end{array}$ \\
\hline$\Delta$ SICC Herfindahl $\mathrm{t}_{\mathrm{t}-1}$ & $\begin{array}{l}-0.0141 \\
(-0.06)\end{array}$ & $\begin{array}{l}0.0277 \\
(0.10)\end{array}$ \\
\hline$\Delta \mathrm{SICC}$ Herfindahl $2_{\mathrm{t}-1}$ & $\begin{array}{l}-0.0032 \\
(-0.01)\end{array}$ & $\begin{array}{l}-0.0334 \\
(-0.13)\end{array}$ \\
\hline$\Delta \operatorname{Ln}(\text { Age })_{\mathrm{t}-1}$ & $\begin{array}{l}-0.0878 \\
(-1.11)\end{array}$ & $\begin{array}{l}-0.1995^{* *} \\
(-2.09)\end{array}$ \\
\hline$\Delta$ Insider Ownership ${ }_{t-1}$ & $\begin{array}{l}0.5624 \\
(1.52)\end{array}$ & $\begin{array}{l}0.5332 \\
(1.37)\end{array}$ \\
\hline$\Delta$ Equity/Total Payt-1 & $\begin{array}{l}0.0479 \\
(1.53)\end{array}$ & $\begin{array}{l}0.0392 \\
(1.21)\end{array}$ \\
\hline$\Delta \mathrm{G}-$ Index $\mathrm{x}_{\mathrm{t}-1}$ & $\begin{array}{l}-0.0161 \\
(-1.01)\end{array}$ & $\begin{array}{l}-0.0176 \\
(-1.00)\end{array}$ \\
\hline$\Delta \mathrm{BCF}$ Index $\mathrm{x}_{\mathrm{t}-1}$ & $\begin{array}{l}0.0746^{* * *} \\
(2.65)\end{array}$ & $\begin{array}{l}0.0579 * \\
(1.90)\end{array}$ \\
\hline$\Delta$ Board Independence $_{t-1}$ & $\begin{array}{l}0.0416 \\
(0.54)\end{array}$ & $\begin{array}{l}0.0422 \\
(0.52)\end{array}$ \\
\hline$\Delta$ Board Size $_{\mathrm{t}-1}$ & $\begin{array}{l}0.0038 \\
(0.82)\end{array}$ & $\begin{array}{l}0.0002 \\
(0.04)\end{array}$ \\
\hline Observations & 958 & 9,958 \\
\hline
\end{tabular}


R-squared

0.061

0.088

Year FE

Yes

Yes

Panel B: Regressions of Change in Diversity in Year $\mathrm{t}$ on Change in Product Innovative Efficiency in Year $\mathrm{t}-1$

\begin{tabular}{|c|c|c|}
\hline Dependent Var. $=\Delta D_{I V}$ & $\Delta \operatorname{Ln}(1+\operatorname{Prod})_{\mathrm{t}-1}$ & $\Delta \operatorname{Ln}[(1+\operatorname{Prod}) /(1+R \& D)]_{\mathrm{t}-1}$ \\
\hline \multirow[t]{2}{*}{$\Delta$ Prod.t-1 $_{1}$} & -0.0032 & 0.0057 \\
\hline & $(-0.13)$ & $(0.26)$ \\
\hline Observations & 8,564 & 8,564 \\
\hline R-squared & 0.214 & 0.214 \\
\hline Year FE & Yes & Yes \\
\hline
\end{tabular}




\section{Table V. Financial Crisis Analysis}

The dependent variables are changes in product innovative efficiency measures in year $t$. The independent variables are changes in net diversity strengths in year $t-1$, along with the changes in controls in year $t$-1. Product innovative efficiency measures include the natural logarithms of one plus the annual number of new product announcements, $\operatorname{Ln}[(1+$ Prod $)$, and of one plus the annual number of new product announcements divided by one plus R\&D expenses, $\operatorname{Ln}[(1+$ Prod $) /(1+R \& D)]$. Crisis is an indicator variable equal to one for years of 2008-2009 and of 20012002, and zero otherwise. Constants are omitted for brevity. All regressions contain year fixed effects. All except binary variables are winsorized at the upper and lower $1 \%$ levels. Full variable definitions are provided in the Appendix. $T$-statistics are reported in parentheses. Standard errors are adjusted based on the Huber-White sandwich estimate of variances and are clustered by firm. *** indicates significance at the $1 \%$ level, ** 5\%, and * 10\%.

\begin{tabular}{|c|c|c|}
\hline & $\Delta \operatorname{Ln}[(1+$ Prod $)]$ & $\Delta \operatorname{Ln}[(1+\operatorname{Prod}) /(1+R \& D)]$ \\
\hline \multirow[t]{2}{*}{ Crisis } & $-0.0617^{*}$ & $-0.1296 * * *$ \\
\hline & $(-1.67)$ & $(-3.12)$ \\
\hline \multirow[t]{2}{*}{ DIV } & $0.0109 *$ & $0.0128 * *$ \\
\hline & $(1.83)$ & $(2.06)$ \\
\hline \multirow[t]{2}{*}{ Crisis*DIV } & $0.0704 * * *$ & $0.0649 * * *$ \\
\hline & $(4.00)$ & $(3.08)$ \\
\hline \multirow[t]{2}{*}{ Crisis*Ln(mv) } & 0.0002 & 0.0209 \\
\hline & $(0.00)$ & $(0.42)$ \\
\hline \multirow[t]{2}{*}{ Crisis*R\&D/Assets } & -0.5756 & 1.4272 \\
\hline & $(-0.45)$ & $(1.00)$ \\
\hline \multirow[t]{2}{*}{ Crisis*Ln(Sales/Employee) } & 0.0005 & -0.0249 \\
\hline & $(0.01)$ & $(-0.23)$ \\
\hline \multirow[t]{2}{*}{ Crisis*CapX/Assets } & -0.6093 & -0.4250 \\
\hline & $(-1.05)$ & $(-0.70)$ \\
\hline \multirow[t]{2}{*}{ Crisis*PPE/Assets } & $0.8643 * *$ & $0.9848 * *$ \\
\hline & $(2.15)$ & $(2.22)$ \\
\hline \multirow[t]{2}{*}{ Crisis*ROA } & -0.4823 & -0.5637 \\
\hline & $(-1.47)$ & $(-1.64)$ \\
\hline \multirow[t]{2}{*}{ Crisis*Debt/Assets } & -0.0839 & -0.1374 \\
\hline & $(-0.40)$ & $(-0.56)$ \\
\hline \multirow[t]{2}{*}{ Crisis*Cash/Assets } & $0.5336^{* *}$ & $0.6239 * *$ \\
\hline & $(2.25)$ & $(2.42)$ \\
\hline \multirow[t]{2}{*}{ Crisis*Q } & $-0.1153 * * *$ & $-0.1563 * * *$ \\
\hline & $(-4.47)$ & $(-5.30)$ \\
\hline \multirow[t]{2}{*}{ Crisis*SICC Herfindahl } & 0.9145 & 0.7767 \\
\hline & $(1.17)$ & $(0.91)$ \\
\hline \multirow[t]{2}{*}{ Crisis*SICC Herfindahl $^{2}$} & -0.7905 & -0.7209 \\
\hline & $(-1.06)$ & $(-0.86)$ \\
\hline \multirow[t]{2}{*}{ Crisis*Ln(Age) } & 0.4632 & $0.7909^{* *}$ \\
\hline & $(1.34)$ & $(1.96)$ \\
\hline \multirow[t]{2}{*}{ Crisis*Insider Ownership } & $2.2355^{*}$ & $2.7057^{*}$ \\
\hline & $(1.68)$ & $(1.91)$ \\
\hline \multirow[t]{2}{*}{ Crisis*Equity/Total Pay } & -0.0575 & -0.0786 \\
\hline & $(-0.65)$ & $(-0.84)$ \\
\hline \multirow[t]{2}{*}{ Crisis*G Index } & -0.0490 & $-0.0714 *$ \\
\hline & $(-1.20)$ & $(-1.68)$ \\
\hline \multirow[t]{2}{*}{ Crisis*BCF Index } & 0.0943 & $0.1566^{* *}$ \\
\hline & $(1.31)$ & (1.97) \\
\hline Crisis*Board Independence & 0.2575 & 0.2774 \\
\hline
\end{tabular}




\begin{tabular}{|c|c|c|}
\hline & $(1.35)$ & $(1.34)$ \\
\hline \multirow[t]{2}{*}{ Crisis*Board Size } & -0.0031 & -0.0014 \\
\hline & $(-0.25)$ & $(-0.10)$ \\
\hline \multirow[t]{2}{*}{$\operatorname{Ln}(\mathrm{mv})$} & $0.0585^{* * *}$ & $-0.0812^{* * *}$ \\
\hline & $(2.72)$ & $(-3.27)$ \\
\hline \multirow[t]{2}{*}{$\mathrm{R} \& \mathrm{D} /$ Assets } & $1.7578 * * *$ & $-8.2177 * * *$ \\
\hline & $(2.67)$ & $(-10.43)$ \\
\hline \multirow[t]{2}{*}{ Ln(Sales/Employee) } & -0.0058 & -0.0273 \\
\hline & $(-0.14)$ & $(-0.62)$ \\
\hline \multirow[t]{2}{*}{ CapX/Assets } & -0.0150 & -0.0048 \\
\hline & $(-0.06)$ & $(-0.02)$ \\
\hline \multirow[t]{2}{*}{ PPE/Assets } & -0.1237 & 0.1238 \\
\hline & $(-0.71)$ & $(0.64)$ \\
\hline \multirow[t]{2}{*}{ ROA } & 0.1875 & 0.1549 \\
\hline & $(1.24)$ & $(0.98)$ \\
\hline \multirow[t]{2}{*}{ Debt/Assets } & 0.0749 & $-0.2199 * *$ \\
\hline & $(0.82)$ & $(-2.16)$ \\
\hline \multirow[t]{2}{*}{ Cash/Assets } & -0.0610 & $0.2081 * *$ \\
\hline & $(-0.62)$ & $(2.01)$ \\
\hline \multirow[t]{2}{*}{ Q } & -0.0220 & $0.0519 * * *$ \\
\hline & $(-1.46)$ & $(3.10)$ \\
\hline \multirow[t]{2}{*}{ SICC Herfindahl } & -0.1615 & -0.0994 \\
\hline & $(-0.63)$ & $(-0.34)$ \\
\hline \multirow[t]{2}{*}{ SICC Herfindahl $^{2}$} & 0.1261 & 0.0834 \\
\hline & $(0.53)$ & $(0.30)$ \\
\hline \multirow[t]{2}{*}{ Ln(Age) } & -0.1451 & $-0.3241 * * *$ \\
\hline & $(-1.64)$ & $(-3.10)$ \\
\hline \multirow[t]{2}{*}{ Insider Ownership } & 0.2956 & 0.2001 \\
\hline & $(0.74)$ & $(0.48)$ \\
\hline \multirow[t]{2}{*}{ Equity/Total Pay } & 0.0546 & 0.0485 \\
\hline & $(1.64)$ & $(1.42)$ \\
\hline \multirow[t]{2}{*}{ G Index } & -0.0019 & 0.0039 \\
\hline & $(-0.10)$ & $(0.20)$ \\
\hline \multirow[t]{2}{*}{ BCF Index } & 0.0487 & 0.0143 \\
\hline & $(1.53)$ & $(0.44)$ \\
\hline \multirow[t]{2}{*}{ Board Independence } & -0.0093 & -0.0152 \\
\hline & $(-0.11)$ & $(-0.17)$ \\
\hline \multirow[t]{2}{*}{ Board Size } & 0.0045 & 0.0006 \\
\hline & $(0.90)$ & $(0.11)$ \\
\hline Observations & 9,958 & 9,958 \\
\hline R-squared & 0.068 & 0.097 \\
\hline Year FE & Yes & Yes \\
\hline
\end{tabular}




\section{Table VI. California versus Non-California Firms}

The dependent variables are natural logarithms of one plus the annual number of new product announcements, Ln[(1+Prod $)$, and of one plus the annual number of new product announcements divided by one plus R\&D expenses, $\operatorname{Ln}[(1+P r o d) /(1+R \& D)]$. All regressions contain firm and year fixed effects. All except binary variables are winsorized at the upper and lower 1\% levels. Full variable definitions are provided in the Appendix. California (Non-California) firms are headquartered in (outside) the State of California. T-statistics are reported in parentheses. Standard errors are adjusted based on the Huber-White sandwich estimate of variances and are clustered by firm. $* * *$ indicates significance at the $1 \%$ level, ** 5\%, and * $10 \%$.

\begin{tabular}{|c|c|c|c|c|}
\hline & \multicolumn{2}{|c|}{ California Firms } & \multicolumn{2}{|c|}{ Non-California Firms } \\
\hline & Ln(1+Prod $)$ & $\operatorname{Ln}[(1+\operatorname{Prod}) /(1+R \& D)]$ & Ln(1+Prod $)$ & $\operatorname{Ln}[(1+\operatorname{Prod}) /(1+R \& D)]$ \\
\hline \multirow[t]{2}{*}{ DIV } & $0.0471 * * *$ & 0.0166 & $0.0201 * * *$ & $0.0165^{*}$ \\
\hline & $(3.02)$ & $(1.02)$ & $(2.68)$ & $(1.87)$ \\
\hline \multirow[t]{2}{*}{$\operatorname{Ln}(\mathrm{mv})$} & 0.0126 & $-0.4109 * * *$ & $0.0533 * *$ & $-0.1885^{* * *}$ \\
\hline & $(0.17)$ & $(-4.64)$ & $(2.43)$ & $(-5.76)$ \\
\hline \multirow[t]{2}{*}{$\mathrm{R} \& \mathrm{D} /$ Assets } & -0.1204 & $-5.4175 * * *$ & $1.7137 * * *$ & $-8.0154 * * *$ \\
\hline & $(-0.12)$ & $(-4.20)$ & $(3.26)$ & $(-9.22)$ \\
\hline \multirow[t]{2}{*}{ Ln(Sales/Employee) } & 0.1551 & 0.0110 & 0.0222 & 0.0471 \\
\hline & $(1.07)$ & $(0.08)$ & $(0.59)$ & $(0.81)$ \\
\hline \multirow[t]{2}{*}{ CapX/Assets } & -0.1860 & -0.6304 & 0.0351 & -0.3145 \\
\hline & $(-0.33)$ & $(-0.71)$ & $(0.14)$ & $(-1.07)$ \\
\hline \multirow[t]{2}{*}{ PPE/Assets } & 0.0055 & -0.0827 & $-0.4801 * * *$ & 0.1331 \\
\hline & $(0.01)$ & $(-0.09)$ & $(-3.32)$ & $(0.62)$ \\
\hline \multirow[t]{2}{*}{ ROA } & 0.0040 & 0.0668 & 0.0453 & -0.2901 \\
\hline & $(0.01)$ & $(0.14)$ & $(0.30)$ & $(-1.57)$ \\
\hline \multirow[t]{2}{*}{ Debt/Assets } & 0.1415 & -0.2742 & 0.0919 & $-0.3348 * * *$ \\
\hline & $(0.64)$ & $(-1.08)$ & $(1.06)$ & $(-3.00)$ \\
\hline \multirow[t]{2}{*}{ Cash/Assets } & -0.0530 & 0.0189 & -0.0072 & $0.3416^{* *}$ \\
\hline & $(-0.22)$ & $(0.07)$ & $(-0.06)$ & $(2.39)$ \\
\hline \multirow[t]{2}{*}{ Q } & -0.0361 & $0.1474 * * *$ & $-0.0976 * * *$ & $0.0584 * * *$ \\
\hline & $(-1.17)$ & $(4.26)$ & $(-5.58)$ & $(2.73)$ \\
\hline \multirow[t]{2}{*}{ SICC Herfindahl } & 1.2573 & 0.2987 & 0.2547 & 0.3200 \\
\hline & $(1.41)$ & $(0.32)$ & $(0.94)$ & $(0.80)$ \\
\hline \multirow[t]{2}{*}{ SICC Herfindahl $^{2}$} & -1.0887 & -0.4788 & -0.3778 & -0.4695 \\
\hline & $(-1.40)$ & $(-0.55)$ & $(-1.53)$ & $(-1.18)$ \\
\hline \multirow[t]{2}{*}{ Ln(Age) } & -0.0964 & -0.1449 & $-0.1239 *$ & -0.0563 \\
\hline & $(-0.43)$ & $(-0.60)$ & $(-1.71)$ & $(-0.60)$ \\
\hline \multirow[t]{2}{*}{ Insider Ownership } & 1.0918 & $1.6505^{*}$ & -0.1570 & -0.0733 \\
\hline & $(1.41)$ & $(1.88)$ & $(-0.62)$ & $(-0.23)$ \\
\hline Equity/Total Pay & 0.1418 & $0.2499 *$ & -0.0303 & 0.0668 \\
\hline
\end{tabular}




\begin{tabular}{|c|c|c|c|c|}
\hline & $(1.12)$ & (1.77) & $(-0.76)$ & $(1.28)$ \\
\hline \multirow[t]{2}{*}{ G Index } & 0.0427 & 0.0388 & 0.0237 & -0.0289 \\
\hline & $(0.56)$ & $(0.46)$ & $(1.04)$ & $(-1.18)$ \\
\hline \multirow[t]{2}{*}{ BCF Index } & 0.0923 & 0.0841 & -0.0365 & 0.0084 \\
\hline & $(0.70)$ & $(0.66)$ & $(-0.93)$ & $(0.14)$ \\
\hline \multirow[t]{2}{*}{ Board Independence } & -0.3151 & 0.0982 & $0.1450^{*}$ & $0.2422 * *$ \\
\hline & $(-1.03)$ & $(0.30)$ & $(1.85)$ & $(2.34)$ \\
\hline \multirow[t]{2}{*}{ Board Size } & $0.0355^{*}$ & 0.0234 & 0.0020 & 0.0033 \\
\hline & $(1.92)$ & $(1.09)$ & $(0.31)$ & $(0.28)$ \\
\hline \multirow[t]{2}{*}{ Constant } & 0.2776 & 0.9877 & 0.6216 & 0.3376 \\
\hline & $(0.21)$ & $(0.79)$ & $(1.42)$ & $(0.62)$ \\
\hline Observations & 1,012 & 1,012 & 10,624 & 10,624 \\
\hline R-squared & 0.285 & 0.285 & 0.150 & 0.097 \\
\hline Firm and Year FE & Yes & Yes & Yes & Yes \\
\hline
\end{tabular}


Table VII. Investigating the Mechanism: Cross-Sectional Heterogeneity

This table reports coefficient estimates on net diversity policies (DIV) and the interactive term between DIV and a dummy variable indicating firms with high (or low) partitioning variable in year $t$ (DIV*I) from the following regression:

$$
I E_{\text {Prod }, i, t+1}=\alpha_{t}+\gamma_{i}+\beta_{1} I_{i, t}+\beta_{2} D I V_{i, t}+\beta_{3} I_{i, t} * D I V_{i, t}+\delta X_{i, t}+\varepsilon_{i, t+1}
$$

where $I$ refers to an indicator variable Ln(1+Prod)_H, PPE/Assets_H, Q_L, Ind Women Ratio_H, LEV/Assets_L, Cash/Assets_H, Q_H, and BCF_H as defined below; $X$ contains all control variables, $\alpha_{t}$ and $\overline{\gamma_{i}}$ are year and firm fixed effects, respectively. The dependent variables, $I E_{P r o d, i, t+1}$ is one of the two new product innovation measures: the natural logarithms of one plus the annual number of new product announcements, $\operatorname{Ln}(1+$ Prod $)$, and of one plus the annual number of new product announcements divided by one plus R\&D expenses, $\operatorname{Ln}[(1+P r o d) /(1+R \& D)]$. Ln(1+Prod)_H equals one (zero) if a firm has $\operatorname{Ln}(1+$ Prod) greater than (equal to) zero-i.e., having at least one (zero) annual new product announcement. PPE/Assets_H equals one (zero) if a firm has PPE/Assets ratio in (below) the top quartile. Q_L equals one (zero) if a firm has Tobin's q in (above) the bottom quartile. Ind Women Ratio_H equals one (zero) if a firm's industry proportion of women employees is in (below) the top quartile of the sample. LEV/Assets_L equals one (zero) if a firm's Debt/Assets ratio is in (above) the bottom quartile of the sample. Cash/Assets_H equals one (zero) if a firm has Cash/Assets ratio in (below) the top quartile. BCF H equals one (zero) if a firm has BCF Index in (below) the top quartile. All regressions contain firm and year fixed effects. All except binary variables are winsorized at the upper and lower 1\% levels. Full variable definitions are provided in the Appendix. T-statistics are reported in parentheses. Standard errors are adjusted based on the Huber-White sandwich estimate of variances and are clustered by firm. *** indicates significance at the $1 \%$ level, $* * 5 \%$, and $* 10 \%$.

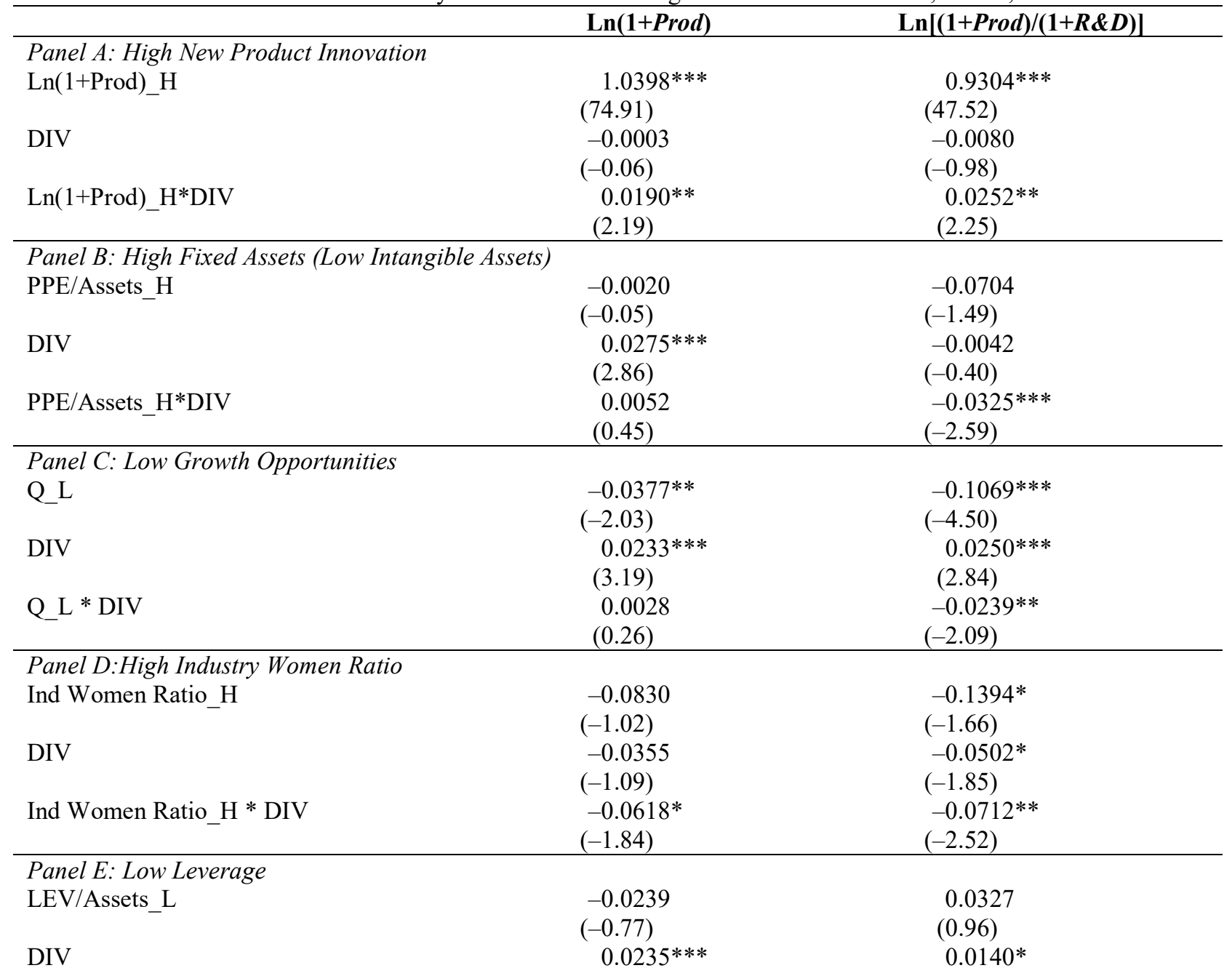




\begin{tabular}{lcc} 
& $(3.25)$ & $(1.69)$ \\
LEV/Assets_L * DIV & 0.0028 & $0.0376^{* *}$ \\
& $(0.19)$ & $(2.12)$ \\
\hline Panel F: High Free Cash Flow & & \\
CASH/Assets_H & $-0.1047^{* * *}$ & $-0.0776^{* *}$ \\
& $(-3.22)$ & $(-2.32)$ \\
DIV & $0.0481^{* * *}$ & $0.0570^{* * *}$ \\
& $(3.40)$ & $(3.41)$ \\
CASH/Assets_H*DIV & $0.0279^{*}$ & $0.0441^{* * *}$ \\
& $(1.95)$ & $(2.67)$ \\
\hline Panel G: High BCF Index (Weak Corporate Governance) & -0.0150 \\
BCF_H & 0.0608 & $(-0.18)$ \\
& $(0.90)$ & 0.0068 \\
DIV & 0.0082 & $(0.55)$ \\
& $(0.84)$ & -0.0208 \\
BCF_H * DIV & $-0.0277^{* *}$ & $(-1.10)$ \\
\hline
\end{tabular}


Table VIII. Diversity, New Product Announcements, and Firm Value

This table reports ordinary least squares regression results of the following equation:

$$
Q_{i, t+1}=\beta_{1} I E_{\text {Prod }, i, t}+\beta_{2} D I V_{i, t-1}+\beta_{3} I E_{\text {Prod }, i, t} * D I V_{i, t-1}+\beta_{4} X_{i, t-1}+\gamma_{i}+\delta_{t}+\varepsilon_{i, t+1}
$$

where $Q_{i, t+1}$ is the market-to-book ratio measured in time $t+1$ for firm $i$ minus industry (the Fama-French 12 industries) median $Q, I E_{\text {Prodi, } i t}$ is one of the two new product innovation measures (defined below) in time $t$ for firm $i$ - used as the dependent variable in the previous sections. $D I V_{i, t-1}$ is measured in time $t-1$ for firm $i$, and $X_{i, t-1}$ contains the full set of controls at time $t-1, \gamma_{i}$ is firm fixed effects, and $\delta_{t}$ is year fixed effects. New product innovation measures include the natural logarithms of one plus the annual number of new product announcements, $\operatorname{Ln}[(1+$ Prod $)$, and of one plus the annual number of new product announcements divided by one plus $\mathrm{R} \& \mathrm{D}$ expenses, $\operatorname{Ln}[(1+\operatorname{Prod}) /(1+R \& D)]$. The sample includes firm-years with at least one annual new product announcement made-i.e., excluding firm-years with zero Prod. All regressions contain firm and year fixed effects. All except binary variables are winsorized at the upper and lower $1 \%$ levels. Full variable definitions are provided in the Appendix. T-statistics are reported in parentheses. Standard errors are adjusted based on the Huber-White sandwich estimate of variances and are clustered by firm. *** indicates significance at the $1 \%$ level, ** 5\%, and * $10 \%$.

\begin{tabular}{|c|c|c|}
\hline Dep. Var. $=\mathbf{Q}_{t+1}$ & Ln(1+Prod $)$ & $\operatorname{Ln}[(1+\operatorname{Prod}) /(1+R \& D)]$ \\
\hline \multirow[t]{2}{*}{ Prod } & 0.0033 & 0.0384 \\
\hline & $(0.10)$ & $(1.16)$ \\
\hline \multirow[t]{2}{*}{ DIV } & -0.0071 & 0.0029 \\
\hline & $(-0.28)$ & $(0.20)$ \\
\hline \multirow[t]{2}{*}{ Prod * DIV } & -0.0049 & $0.0082 * *$ \\
\hline & $(-0.51)$ & $(2.02)$ \\
\hline \multirow[t]{2}{*}{$\operatorname{Ln}(\mathrm{mv})$} & $-0.2088 * * *$ & $-0.1955^{* * *}$ \\
\hline & $(-3.99)$ & $(-3.43)$ \\
\hline \multirow[t]{2}{*}{$\mathrm{R} \& \mathrm{D} /$ Assets } & 1.0715 & 1.3060 \\
\hline & $(1.12)$ & $(1.28)$ \\
\hline \multirow[t]{2}{*}{$\operatorname{Ln}($ Sales/Employee $)$} & 0.1453 & 0.1420 \\
\hline & $(1.16)$ & $(1.14)$ \\
\hline \multirow[t]{2}{*}{ CapX/Assets } & $-1.3039 * *$ & $-1.2914 * *$ \\
\hline & $(-2.23)$ & $(-2.21)$ \\
\hline \multirow[t]{2}{*}{ PPE/Assets } & -0.4750 & -0.4721 \\
\hline & $(-1.21)$ & $(-1.21)$ \\
\hline \multirow[t]{2}{*}{ ROA } & 0.5141 & 0.5412 \\
\hline & $(0.97)$ & $(1.02)$ \\
\hline \multirow[t]{2}{*}{ Debt/Assets } & $-0.3452 * *$ & $-0.3285^{*}$ \\
\hline & $(-1.98)$ & $(-1.90)$ \\
\hline \multirow[t]{2}{*}{ Cash/Assets } & -0.3209 & -0.3317 \\
\hline & $(-1.00)$ & $(-1.01)$ \\
\hline \multirow[t]{2}{*}{ Q } & $0.2379 * * *$ & $0.2327^{* * *}$ \\
\hline & $(5.42)$ & $(5.22)$ \\
\hline \multirow[t]{2}{*}{ SICC Herfindahl } & 0.1537 & 0.1573 \\
\hline & $(0.29)$ & $(0.30)$ \\
\hline \multirow[t]{2}{*}{ SICC Herfindahl ${ }^{2}$} & -0.2712 & -0.2594 \\
\hline & $(-0.59)$ & $(-0.57)$ \\
\hline \multirow[t]{2}{*}{ Ln(Age) } & -0.0631 & -0.0522 \\
\hline & $(-0.37)$ & $(-0.31)$ \\
\hline \multirow[t]{2}{*}{ Insider Ownership } & -0.3652 & -0.3979 \\
\hline & $(-0.54)$ & $(-0.59)$ \\
\hline \multirow[t]{2}{*}{ Equity/Total Pay } & 0.0936 & 0.0921 \\
\hline & (1.08) & (1.08) \\
\hline \multirow[t]{2}{*}{ G Index } & 0.0227 & 0.0222 \\
\hline & $(0.54)$ & $(0.53)$ \\
\hline
\end{tabular}




\begin{tabular}{lcc} 
BCF Index & -0.0033 & 0.0049 \\
& $(-0.05)$ & $(0.08)$ \\
Board Independence & 0.0282 & 0.0225 \\
& $(0.12)$ & $(0.10)$ \\
Board Size & -0.0151 & -0.0152 \\
& $(-1.51)$ & $(-1.52)$ \\
Constant & 1.3154 & 0.2427 \\
& $(1.09)$ & $(0.22)$ \\
\hline Observations & $4,883 \quad 4,883$ & \\
R-squared & 0.182 & $0.183 \quad$ Yes \\
Firm and Year FE & \multicolumn{1}{c}{ Yes } & \\
\hline
\end{tabular}


Table IX. Robustness Using Patent and Citation Innovative Efficiency Measures

Panel A reports the baseline regressions of patent innovative efficiency measures on net diversity. The dependent variables are natural logarithms of one plus patent innovative efficiency (IE) (Models 1 and 2) and citation innovative efficiency (Models 3 and 4). In Models 1 and 3, the IE measures have been adjusted for the US Patent Office technology groups, while in Models 2 and 4, we use the Hall et al. (2001) technology classifications. Panel B reports causality by running changes on changes regressions. In Panel B-1, the dependent variables are changes in patent innovative efficiency (IE) (Models 1 and 2) and citation innovative efficiency (Models 3 and 4) in year $t$. The independent variables are changes in net diversity in year $t-1$, along with the changes in controls in year $t-1$. In Panel B-2, the dependent variables are changes in respectively net diversity in year $t$. The independent variables are changes in respectively the four innovative efficiency measures in year $t-1$, along with the changes in controls in year $t-1$. Panel B reports ordinary least squares regression results of the following equation:

$$
Q_{i, t+1}=\beta_{1} I E_{i, t}+\beta_{2} D I V_{i, t-1}+\beta_{3} I E_{i, t} \times D I V_{i, t-1}+\beta_{4} X_{i, t-1}+\gamma_{i}+\delta_{t}+\varepsilon_{i, t+1}
$$

where $Q_{i, t+1}$ is the market-to-book ratio measured in time $t+1$ for firm $i$ minus industry (the Fama-French 12 industries) median $Q, I E_{i, t}$ is the natural logarithm of one plus one of the four innovative efficiency measures in time $t$ for firm $i$ - used as the dependent variable in the previous sections, $D I V_{i, t-1}$ is measured in time $t-1$ for firm $i$, and $X_{i, t-1}$ contains the full set of controls at time $t-1, \gamma_{i}$ is firm fixed effects, and $\delta_{t}$ is year fixed effects. All control variables are included but omitted for brevity. All except binary variables are winsorized at the upper and lower $1 \%$ levels. Full variable definitions are provided in the Appendix. T-statistics are reported in parentheses. Standard errors are adjusted based on the Huber-White sandwich estimate of variances and are clustered by firm. *** indicates significance at the $1 \%$ level, ** 5\%, and * $10 \%$.

\begin{tabular}{|c|c|c|c|c|}
\hline \multicolumn{5}{|c|}{ Panel A: Baseline Regressions of Patent Innovative Efficiency on Net Diversity } \\
\hline & \multicolumn{2}{|c|}{$\operatorname{Ln}\left(1+\mathrm{IE} \mathrm{EAT}_{\mathrm{T}}\right)$} & \multicolumn{2}{|c|}{$\operatorname{Ln}\left(1+\mathbf{I E}_{\text {CITE }}\right)$} \\
\hline \multirow{3}{*}{ DIV } & & & & \\
\hline & $0.0025 * * *$ & $0.0006^{* *}$ & $0.0065^{*}$ & $0.0066^{* *}$ \\
\hline & (2.66) & $(2.06)$ & (1.88) & $(2.14)$ \\
\hline Firm and Year FE & Yes & Yes & Yes & Yes \\
\hline Observations & 3,239 & 3,239 & 3,239 & 3,239 \\
\hline R-squared & 0.179 & 0.138 & 0.212 & 0.224 \\
\hline \multicolumn{5}{|c|}{ Panel B: Addressing Causality: Change on Change Regressions } \\
\hline \multicolumn{5}{|c|}{ Panel B-1: Regressions of Change in Innovative Efficiency in Year $\mathrm{t}$ on Change in Diversity in Year $\mathrm{t}-1$} \\
\hline & \multicolumn{2}{|c|}{$\Delta \operatorname{Ln}\left(1+\mathbf{I E}_{\mathrm{PAT}}\right)_{\mathrm{t}}$} & \multicolumn{2}{|c|}{$\Delta \mathbf{L n}\left(1+\mathbf{I E}_{\text {CITE }}\right)_{t}$} \\
\hline \multirow{3}{*}{$\begin{array}{l}\text { Dependent Var. }=\mathbf{I E}_{\mathbf{t}} \\
\Delta \mathrm{DIV}_{\mathrm{t}-1}\end{array}$} & USPTO & HJT & USPTO & HJT \\
\hline & $0.0016^{*}$ & 0.0004 & 0.0048 & $0.0053^{*}$ \\
\hline & (1.65) & (1.31) & $(1.29)$ & $(1.72)$ \\
\hline Observations & 2,499 & 2,499 & 2,499 & 2,499 \\
\hline R-squared & 0.006 & 0.008 & 0.012 & 0.025 \\
\hline \multicolumn{5}{|c|}{ Panel B-2: Regressions of Change in Diversity in Year $\mathrm{t}$ on Change in Innovation in Year $\mathrm{t}-1$} \\
\hline & \multicolumn{4}{|c|}{ Independent Variable } \\
\hline \multirow[b]{2}{*}{$\begin{array}{l}\text { Dependent Var. }= \\
\Delta \text { DIV }_{t}\end{array}$} & \multicolumn{2}{|c|}{$\Delta \operatorname{Ln}\left(1+\mathbf{I E}_{\mathrm{PAT}}\right)_{\mathrm{t}-1}$} & \multicolumn{2}{|c|}{$\Delta \operatorname{Ln}\left(1+\mathbf{I E}_{\text {CITE }}\right)_{\mathrm{t}-1}$} \\
\hline & USPTO & HJT & USPTO & HJT \\
\hline \multirow[t]{2}{*}{$\Delta$ Innov. Eff.t-1 } & 0.5906 & 2.1924 & 0.1561 & 0.0458 \\
\hline & $(0.83)$ & $(0.79)$ & $(1.00)$ & $(0.31)$ \\
\hline Observations & 1,638 & 1,638 & 1,638 & 1,638 \\
\hline R-squared & 0.020 & 0.020 & 0.021 & 0.020 \\
\hline
\end{tabular}




\begin{tabular}{lcccc}
\hline \multicolumn{4}{l}{ Panel C: Regressions of Firm Value on the Interaction of Diversity and Innovative Efficiency } \\
\hline \multicolumn{2}{c}{ Ln(1+IEPAT) } & \multicolumn{2}{c}{ Ln(1+IEciTE) } \\
Dep. Var. $=\mathbf{Q}_{t+\mathbf{1}}$ & USPTO & HJT & USPTO & HJT \\
\hline IE & -0.8494 & -2.3283 & -0.1065 & -0.0683 \\
& $(-1.57)$ & $(-1.25)$ & $(-0.76)$ & $(-0.43)$ \\
DIV & $-0.1135^{* * *}$ & $-0.1140^{* * *}$ & $-0.1120^{* * *}$ & $-0.1112^{* * *}$ \\
& $(-3.40)$ & $(-3.42)$ & $(-3.43)$ & $(-3.41)$ \\
IE * DIV & $1.0815^{*}$ & $3.7117^{* *}$ & $0.2583^{*}$ & 0.2312 \\
& $(1.90)$ & $(2.00)$ & $(1.67)$ & $(1.49)$ \\
Firm and Year FE & Yes & Yes & Yes & Yes \\
Observations & 3,046 & 3,046 & 3,046 & 3,046 \\
R-squared & 0.167 & 0.166 & 0.166 & 0.165 \\
\hline
\end{tabular}

